\title{
Late Sandbian (Sa2) radiolarians of the Pingliang Formation from the Guanzhuang section, Gansu Province, China
}

\author{
Siyumini Perera (D) and Jonathan C. Aitchison* (1)
}

School of Earth and Environmental Sciences, The University of Queensland, St. Lucia, 4072, Queensland, Australia <p.perera@uq.edu.au> and <jona@uq.edu.au>

\begin{abstract}
A diverse, well-preserved radiolarian assemblage is reported from the Sandbian age Climacograptus bicornis Graptolite Biozone. This new assemblage, recovered from the Pingliang Formation in the Guanzhuang section, China, includes six new species along with 13 other previously described taxa. Geminusphaera new genus incorporates G. grandis n. sp. and G. kongtongensis n. sp. and is proposed for inaniguttids constructed from two distinct porous spheres bearing seven or more primary spines. Protopylentonema new genus is introduced to incorporate pylomate entactinarians with five-rayed initial spicules. It includes $P$. ordosensis $\mathrm{n}$. sp. as well as $P$. aperta, $P$. rimata, and $P$. insueta that were formerly assigned to Kalimnasphaera. Micro-computed tomography investigation of skeletal microstructure supports establishment of the new genera together with other new spumellarian species: Haplotaeniatum implexa n. sp., Inanigutta quadrispinosa $\mathrm{n}$. sp., and Kalimnasphaera pingliangensis $\mathrm{n}$. sp. It also indicates that family-level reassignment of Etymalbaillella from the Proventocitidae to the Ceratoikiscidae is appropriate.

Global distribution of Late Ordovician radiolarian occurrences highlights a strong preference for areas with equatorial to tropical sea surface temperatures. This must have led to ecological stress among radiolarian communities in adapting to global cooling in the Hirnantian.
\end{abstract}

UUID: http://zoobank.org/3d3f55b8-0e70-4f9f-9738-265750d8ec3a.

\section{Introduction}

Taxonomic research on early Paleozoic radiolarians from isolated occurrences is progressing rapidly compared to that for biostratigraphic correlation and paleoecological investigations, resulting in an improved understanding of systematics over the past two decades. Western Newfoundland, where more than a dozen radiolarian studies have been conducted during the last three decades, is one of the most intensively studied areas with numerous Lower and Middle Ordovician localities (Aitchison et al., 1998; Won and Iams, 2002, 2011, 2013, 2015a, b; Won et al., 2005, 2007; Maletz, 2007; Pouille et al., 2014; Kachovich and Aitchison, 2020, 2021). Similarly, the Guanzhuang section, Pingliang, China, is the most well-known locality for Upper Ordovician (Sandbian) radiolarians. It is stratigraphically well calibrated using abundant graptolites and conodonts in shale and limestone beds and was once a candidate for the Global Boundary Stratotype Section (GSSP) of the base of Upper Ordovician (Sun, 1933; Chen et al., 1984; Finney et al., 1999; Wang et al., 2013). Despite its importance, the Pingliang Formation has been explored only twice for radiolarians. The first investigation was nearly 30 years ago (Wang, 1993), with the second two decades later (Wang et al., 2010). This paper undertakes

*Corresponding author the first systematic investigation of radiolarian diversity of the Climacograptus bicornis Biozone in the Guanzhuang section. It discusses and resolves various long-held disputes regarding the status of several genera in the family Inaniguttidae with observations from models created using micro-computed tomography (micro-CT).

Samples examined in this study yielded a diverse, wellpreserved assemblage with 19 radiolarian species representing 12 genera. Two new genera are introduced together with six new species and systematics are revised for all the taxa recovered. This diverse, well-preserved assemblage from the Guanzhuang section provides the first record of radiolarians from the late Sandbian (Sa2; Upper Ordovician) C. bicornis Graptolite Biozone. It bears similarity to both the collection of radiolarians reported by Wang (1993) from the same section and assemblages described from eastern Kazakhstan by Nazarov and Popov (1980).

\section{Geological setting}

Locality information.-The Guanzhuang section is the type locality of the Pingliang Formation and located near Yindong, Guanzhuang, Kongtong District, $\sim 8 \mathrm{~km} \mathrm{SW}$ of Pingliang City, Gansu Province, China $\left(35^{\circ} 29^{\prime} 32^{\prime \prime} \mathrm{N}, 1^{\circ} 36^{\prime} 31^{\prime \prime} \mathrm{E}\right.$, WGS 84; Fig. 1). This naturally exposed, $\sim 90 \mathrm{~m}$ high, steep cliff is easily accessible and located alongside a small creek. 


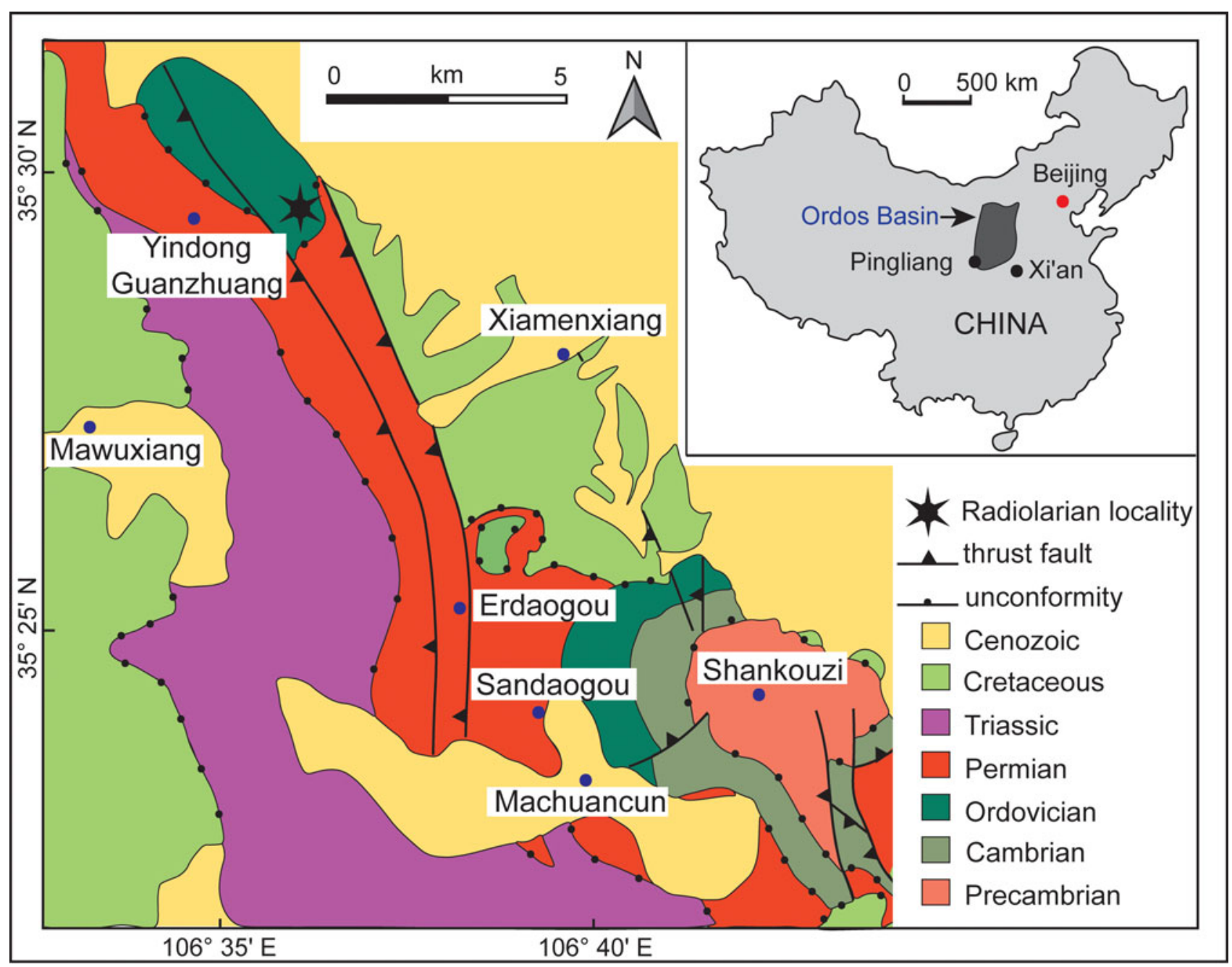

Figure 1. Geological map of the Pingliang region, Gansu Province, China (modified after Sun et al., 2020); inset map shows the location of the Ordos Basin.

Sedimentary rocks in the section are part of one of five sub-basins comprising the southwest Ordos Basin, which experienced several transitions in sedimentary facies throughout the Middle-Upper Ordovician (Chen et al., 2017; Dai et al., 2019; Yang et al., 2019).

Sediments at Guanzhuang were deposited in a carbonate platform-marginal slope environment, with deposition of Pingliang Formation interpreted to have occurred in a convergent-margin, back-arc setting in response to a series of tectonic events associated with the Qinling Orogeny (Wang et al., 2015a, b; Yang et al., 2015; Zhang et al., 2019). A few minor folds and faults can be observed, but the stratigraphy of the Ordovician succession is not significantly disrupted by tectonic activities.

Stratigraphic context.-The Guanzhuang section is $\sim 100 \mathrm{~m}$ thick. It overlies the Lower Ordovician Sandaogou Formation at its base and is unconformably overlain by the lower Permian Shanxi Formation (Fig. 2). It consists predominantly of limestone and shale with thin intercalations of sandstone, calcareous mudstone, and some debris flow deposits. A diverse assemblage of graptolites and conodonts extracted from shale and carbonate layers constrain the succession to the Sandbian, which is widely considered to represent the best example of the boundary between the Nemagraptus gracilis and C. bicornis biozones (Finney et al., 1999; Wang et al., 2013; Chen et al., 2017).

Levels previously examined for radiolarians by Wang (1993) and Wang et al. (2010) are stratigraphically lower than those from which the two samples that produced the assemblage described herein were collected (see Fig. 2). Both previous studies on Pingliang radiolarians are from the $N$. gracilis Graptolite Biozone. Wang (1993) assigned a radiolarian fauna from bed 3 in the Pingliang section (after Chen et al., 1984) to the Syndyograptus subzone of the $N$. gracilis Biozone. This $27.5 \mathrm{~m}$ thick unit begins $13 \mathrm{~m}$ above the base of the section. The conodont assemblage Pygodus anserinus, Periodan aculeatus Hadding, 1913, and Pygodus serra (Hadding, 1913) occurs in beds 2-8 (Wang, 1993) representing the entirety of upper Darriwilian (Dw3) to lower Sandbian (Sa1). Co-occurring graptolites include $N$. gracilis and C. bicornis, which range through the Sandbian (Sa1 and Sa2) (Wang, 1993). Although Chen et al. (1984) provided an account of graptolites and conodonts from bed 3, no age-specific taxa were included other than mentioning 


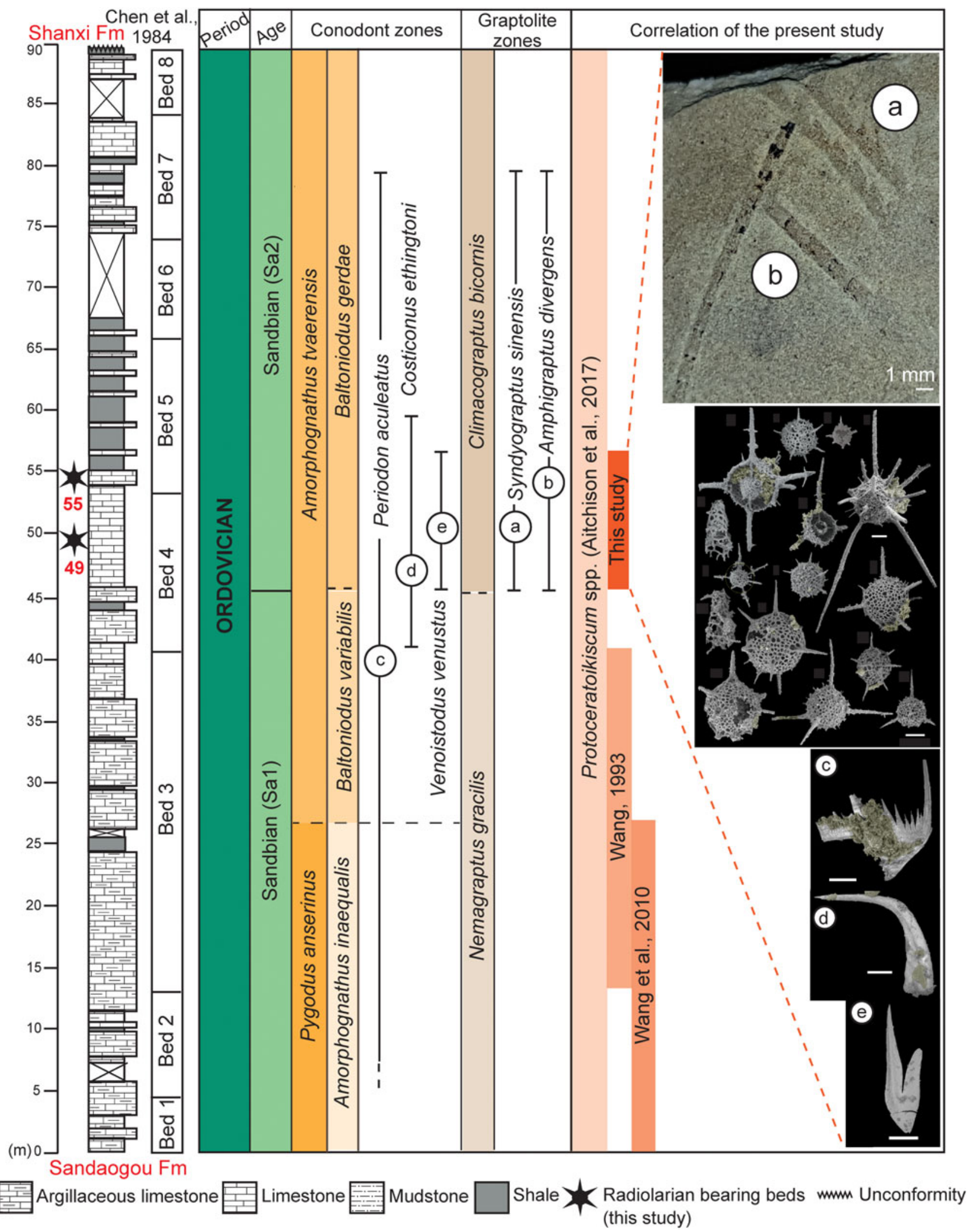

Figure 2. Lithostratigraphy of the Pingliang Formation in the Guanzhuang section (modified after Wang et al., 2013) and correlation of biozones with co-occurring conodonts and graptolites. Scale bars are $100 \mu \mathrm{m}$ where not specified. 
that bed 4 contains $N$. gracilis and $P$. anserinus. Later conodont and graptolite studies of the Guanzhuang section (Wang et al., 2013; Chen et al., 2017; Dai et al., 2019) allow improved correlation of the radiolarian assemblage from bed 3, which can be assigned to the Sandbian (Sa1) N. gracilis Biozone. Wang et al. (2010) examined the basal section of the Guanzhuang succession and introduced the radiolarian genus Gansuceratoikiscum occurring within the Pygodus anserinus Conodont Biozone.

\section{Materials and methods}

Faunas described herein were extracted from micritic limestone samples collected from the Pingliang Formation in the Guanzhuang section. From 56 limestone samples, two samples yielded well-preserved radiolarians whereas most other samples only had poorly preserved, unrecognizable forms.

Samples were crushed into $\sim 5 \mathrm{~cm}^{3}$ pieces to increase the reaction surface area prior to chemical digestion in order to release radiolarians from their surrounding matrix. Fragments were etched in $10 \%$ acetic acid for up to 12 weeks in the micropaleontology laboratory of the School of Earth and Environmental Sciences (SEES) of the University of Queensland. The residue produced through this slow etching process was later wet-sieved and the fraction between $500 \mu \mathrm{m}$ and $63 \mu \mathrm{m}$ was collected and air-dried. The procedure was repeated until a representative assemblage of radiolarians was recovered. Wellpreserved, biostratigraphically significant radiolarians were individually picked under Leica M80 light microscope and later imaged using a desktop Hitachi TM3030 SEM.

Seven specimens with disputed and previously uncertain taxonomic affiliations were selected for detailed examination: Etymalbaillella toriterminalis Li, 1995; Haplentactinia baltica (Nazarov and Nolvak, 1983), Haplotaeniatum implexa n. sp., Geminusphaera kongtongensis n. gen. n. sp., Inanigutta quadrispinosa n. sp., Kalimnasphaera pingliangensis n. sp., and Protopylentonema ordosensis n. gen. n. sp. All were scanned to produce two-dimensional tomographs using a Zeiss Xradia Versa XRM-500 high-resolution micro-CT scanner at the Julius Kruttschnitt Mineral Research Centre, The University of Queensland, following the method developed by Kachovich et al. (2019). Avizo® 9.7 volume rendering software was used to generate 3D models of the specimens, which were subsequently used to facilitate taxonomic interpretations.

Repositories and institutional abbreviations.-Specimens examined in this study are deposited in the micropaleontology collection of the School of Earth and Environmental Sciences, The University of Queensland, Australia (SEES-UQ). SEES/ 140703 refers to the collection number, while the middle two digits and the last three characters of the specimen identification number (SEES/140703-XX-YYY) correspond to the sample number and species identification number, respectively. Other repositories mentioned herein include Geological Institute, Moscow (GIN); Department of Geology, Tallinn University of Technology, Estonia (GIT); Paleontological Collection, Department of Geology of University of Alberta (UA); Institute of Geology, Beijing (BGIN); Nanjing Institute of Geology and
Paleontology, Chinese Academy of Sciences (NIGPAS); and Australian Museum (AM.F).

\section{Systematic paleontology}

Phylum Radiozoa Cavalier-Smith, 1987

Class Polycystina Ehrenberg, 1838, sensu Riedel, 1967

Order Albaillellaria Deflandre, 1953, emend. Holdsworth, 1969

Remarks.-The order Albaillellaria was introduced by Deflandre (1953). Holdsworth (1969b) revised the initial diagnosis to incorporate Ceratoikiscidae within the Albaillellaria. The order can be traced to the Ordovician with the earliest genus, Protoceratoikiscum Goto et al. (1992). The basic skeletal framework of Albaillellaria is composed of three fundamental elements referred to as intersector, a-bar, and b-bar, which might differ in their length, position, or shape depending on the genus. These basic elements are clearly expressed in Albaillellidae and Ceratoikiscidae, while Follicucullidae display a reduced and simpler skeleton. Several authors have proposed a homologous relationship between Ceratoikiscidae and Albaillellidae that is explained via phylogenetic models reflecting the possibility of a common ancestor, possibly a primitive ceratoikiscid in the early Paleozoic (Foreman, 1963; Holdsworth, 1969a, b; Won, 1983; Cheng, 1986; Renz, 1988; Aitchison, 1993). To accommodate all the genera from Ordovician to earliest Triassic that are presently assigned to this order, one should assume the initial skeleton of albaillellarians has undergone extensive modifications along the evolutionary pathway. De Wever et al. (2001) remarked, that during these skeletal alterations, albaillellarians were successful enough to always conserve at least one out of their three skeletal elements.

\section{Family Ceratoikiscidae Holdsworth, 1969, sensu Holdsworth, 1977}

Remarks.-Initially this family included Ceratoikiscum and Holoeciscus, but has now been expanded to include more than a dozen genera spanning from Ordovician-Carboniferous. Foreman (1963) introduced the basic nomenclature to describe the skeletal elements of ceratoikiscids, which was elaborated on later by several authors (Holdsworth, 1969b; Renz, 1988; Noble and Lenz, 2007) (see Fig. 3.1, 3.2). Throughout their evolution, an architecture involving three principal rods that might have slightly reshaped or suppressed is retained as the most conspicuous feature of the Ceratoikiscidae, compared to highly variable development of patagial tissue and/or caveal ribs. Wakamatsu et al. (1990) stated that modifications among the caveal ribs are better regarded as features of lower levels of classifications. However, even the indisputable most primitive species, Protoceratoikiscum clarksoni Danelian and Floyd, 2001, recovered from the Middle to Upper Ordovician chert beds in Southern Uplands, Scotland, displays a characteristic 'triangular structure' made from two primary spines and a straight by-spine that closely resembles the basic architecture of the three principal rods. 


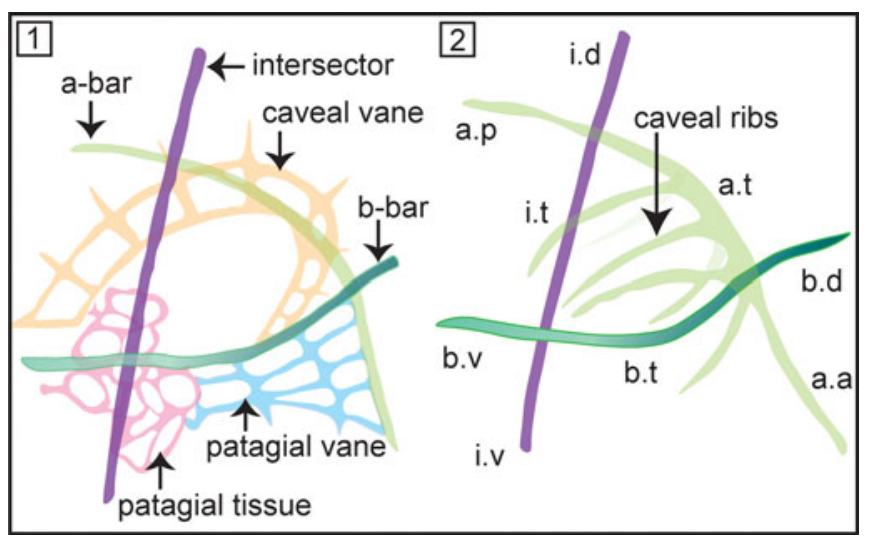

Figure 3. (1) Nomenclature describing the structural details of Ceratoikiscum. (2) Anatomical notation of the frame of Ceratoikiscum. i.d = intersector (extratriangular) dorsal portion; i.t $=$ intersector triangle forming portion; i.v $=$ intersector (extratriangular) ventral portion; a.p $=\mathrm{a}$-rod (extratriangular) posterior portion; $\mathrm{a} \cdot \mathrm{t}=\mathrm{a}-\mathrm{rod}$ triangle forming portion; $\mathrm{a} \cdot \mathrm{a}=\mathrm{a}-\operatorname{rod}($ extratriangular $)$ anterior portion; b.d = b-rod (extratriangular) dorsal portion; b.v = b-rod (extratriangular) ventral portion; b.t = b-rod triangle forming portion (after Holdsworth, 1969b).

\section{Genus Etymalbaillella Li, 1995}

Type species.-Etymalbaillella yennienii Li, 1995 (BGIN 930311) from the Baijingsi, Qilian Mountains, China, by original designation.

Diagnosis.-Conical radiolarians with the patagium developed into a latticed framework enveloping the sub-triangular initial skeleton made of a prominent intersector along with a-bar and b-bar blended into the lattice. Bears an open anterior end and may have projections attached to the a-bar and intersector. Emended from Li (1995).

Remarks.-Etymalbaillella was first assigned to the Albaillellidae by $\mathrm{Li}$ (1995). Constituent species include E. renzii, E. toriterminalis, and E. yennienii that were first reported from Baijingsi, Qilian Mountains, China (Li, 1995). Etymalbaillella was later grouped with Proventocitum and reassigned under the Proventocitiidae (Aitchison, 1998). Noble and Webby (2009) recovered E. yennienii from the Malongulli Formation in Australia. To reflect the uncertainty about this assignment and to highlight the need for further investigation, it was placed under incertae sedis at both the Order and Family level by Noble et al. (2017). Known occurrences are significant because they come from deep marine (Li, 1995) and shallow marine (Noble and Webby, 2009) facies. Both have yielded well-preserved shells in spite of their delicate nature. With reference to observations based on specimens observed in this study, the authors disagree with the comments of Noble and Webby (2009) on the lack of two lateral rods mentioned by $\mathrm{Li}$ (1995) and the absence of albaillellid symmetry. In his discussion of the genus, $\mathrm{Li}$ (1995, p. 338) noted the existence of "two rods along dorsal and ventral shell walls" united by "trabeculaea of circumferential ridge." The nomenclature he applied reflects a preference towards the family Albaillellidae.

Considering the extensive discussions of phylogeny and homologies between Albaillellidae and Ceratokiscidae
(Holdsworth, 1969a, 1971; Won, 1983; Cheng, 1986; Renz, 1988; Aitchison, 1993), both the aforementioned families undeniably share an architecture involving three principal rods, more or less modified depending on the context. The skeletal architecture that separates Ceratokiscidae and Albaillellidae is subtle, such that even a slight modification to the configuration can prompt confusion, which easily could make the case for a primitive morphotype. Therefore, emphasis should be placed on the stratigraphic continuity of forms when skeletal architecture is not obvious enough to proceed with a solid phylogenetic assignment. Cheng (1986) remarked that acquisition of a shell, offset trabeculae on two rods, and wings, developed at a much later evolutionary stage. This explains the first occurrence of Albaillellidae in the Late Devonian (Cheng, 1986), while ceratokiscids made their entrance by the Middle Ordovician (Danelian and Floyd, 2001). In spite of superficial resemblance of Etymalbaillella to Albaillella, there is little evidence to fill the stratigraphic gap between the first known occurrences of Albaillella and Etymalbaillella. This indicates the possibility of assigning Etymalbaillella to the Ceratoikiscidae because it also shares the same three-rod architecture and is compatible with the period of origin. Nevertheless, the possibility of finding a morphotype intermediate between Albaillella and Etymalbaillella in the stratigraphic gap cannot be completely eliminated, in which case further family-level revision may be required.

\section{Etymalbaillella toriterminalis $\mathrm{Li}, 1995$}

Figures 4, 11.5

1995 Etymalbaillella toriterminalis Li, p. 338, pl. 2, figs. 12, 16.

Holotype.-Neotype specimen no. SEES/140703-55-ET1 (Fig. 11.5) and SEES/140703-49-ET2 (digitized as Fig. 4 and Supplemental Data 1) from Sandbian limestone beds in the Pingliang Formation, Guanzhuang section, Gansu Province, China.

Diagnosis. - Conical skeleton composed of a latticed framework supported by and merged into the three-rod ceratoikiscid architecture; intersector, a-bar, and b-bar. B-bar extends laterally forming extratriangular segments at ventral and anterior positions. Slightly inflated close to the point of convergence between a-bar and intersector. Emended from Li (1995).

Description.-Observations using micro-CT reveals important skeletal features that suggest possible phylogenetic affiliation to the Ceratoikiscidae or Albaillellidae. Careful segmentation of the E. toriterminalis skeleton reveals the presence of an almost straight intersector (Fig. 4.6) along with an a-bar (Fig. 4.4) and b-bar (Fig. 4.5) blended with the latticed shell that forms the fundamental initial skeleton in ceratoikiscids and albaillellids. Intersections of the intersector with the b-bar and the a-bar with the b-bar produce prominent extratriangular segments at ventral and anterior junctions, respectively (Fig. 4.8). Extensions of the b-bar beyond the shell frame have the appearance of a pair of wings and show a maximum length of $80 \mu \mathrm{m}$. A-bar shows a slightly offset branching and makes up the lattice frame along with 1-2 wing-like 


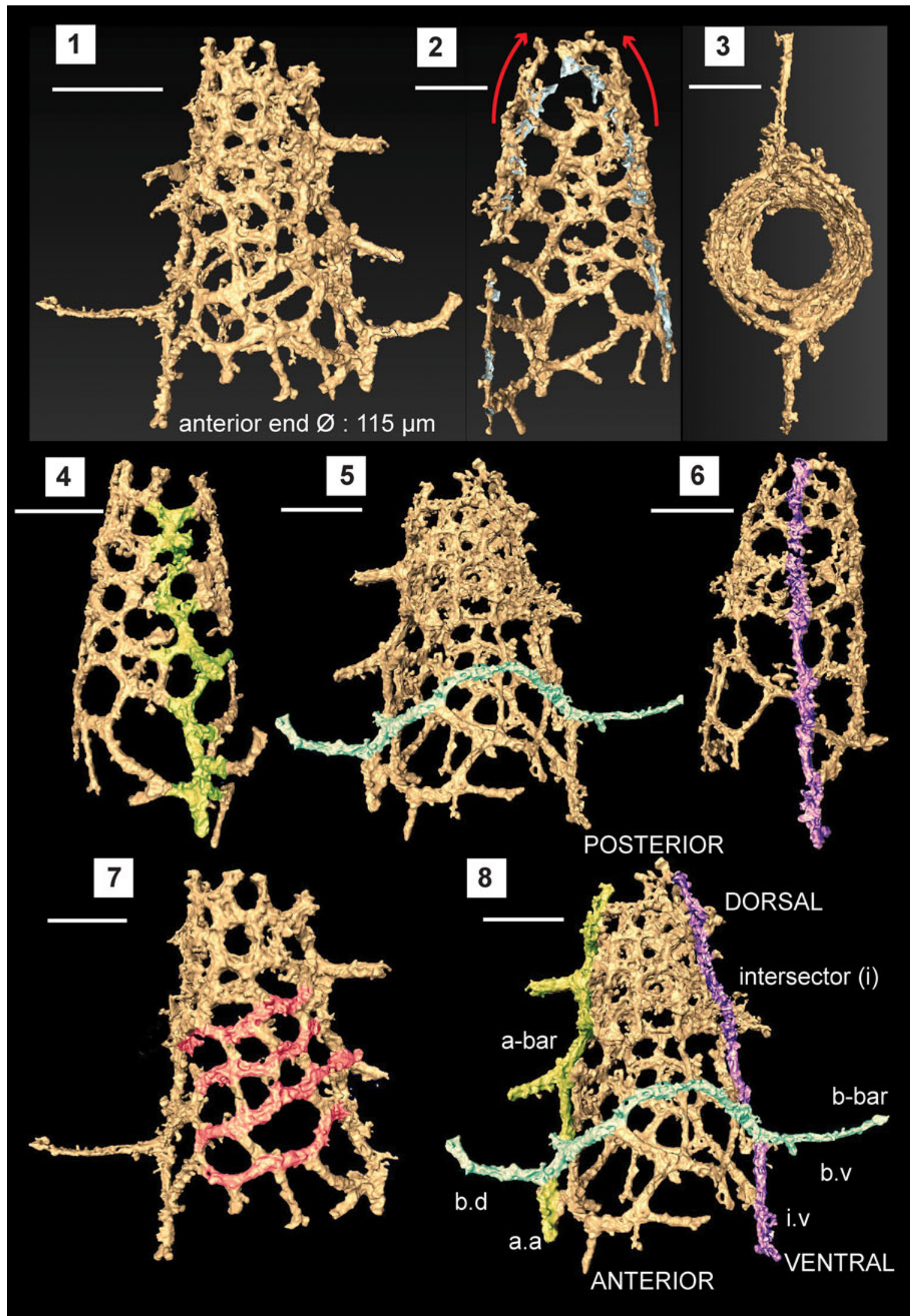

Figure 4. Structural details highlighted using a micro-CT model of Etymalbaillella toriterminalis (SEES/140703-49-ET2). (1) Complete specimen of E. toriterminalis; (2) inflated top area of the shell; (3) view from the anterior end towards the apex highlighting the skeleton symmetry; (4) a-bar blended into the lattice shell (Ortho view); (5) b-bar blended into the lattice shell (Ortho view); (6) intersector (Ortho view); (7) diagonal configuration of interpore areas, possibly indicating traces of caveal ribs; (8) anatomical notation of frame with ventral side facing front; a.a = a-bar (anterior portion); b.d = b-bar (dorsal portion) b.v = b-bar (ventral portion); i.v $=$ intersector (ventral portion). Scale bars $=100 \mu \mathrm{m}$. 
extensions that project outwards from the shell. These wing-like extensions from the a-bar are much shorter than dorsal and ventral portions of the b-bar (Fig. 4.8). The shell is slightly inflated close to the point of convergence between the a-bar and intersector, which could be a result of the tendency of the a-bars to curve when present in typical ceratoikiscid frames (Fig. 4.2). There are no conspicuous caveal ribs, but it may be assumed that they have been reduced in forming the lattice frame in conjunction with the patagium. The continuous diagonal inter-pore areas highlighted in Figure 4.7 also can be interpreted as residual traces of caveal ribs.

Pores in the lattice are sub-rounded to polygonal and are arranged diagonally in rows. These pores gradually reduce in size towards the posterior end of the intersector. Lattice meshwork may be considered a type of primitive equivalent to the patagium seen in Ceratoikiscidae, although patagial vanes or tissue cannot be resolved specifically. The vertical length of the entire conical shell made of the latticed framework is $225 \mu \mathrm{m}$, excluding the possibly broken apex. The widely open anterior end is $115 \mu \mathrm{m}$ in diameter $(\varnothing)$, but is less than $65 \mu \mathrm{m}$ at the posterior end. All specimens encountered have open posterior ends, although they can be interpreted as broken ends possibly as a result of taphonomic conditions.

Remarks.-This is the first report of E. toriterminalis after the initial discovery from Baijingsi, Qilian Mountains in China. The original type material (BGIN 930851) has been destroyed (Li Hongsheng personal communication, 2020, via Luo Hui), so a neotype (SEES/140703-55-ET1) is designated herein. Specimens are extremely delicate and frequently leave behind molds upon fragmentation. Use of the terms adopted herein to describe the structural details of the species follows the terminology and the definitions revised by Holdsworth (1969b). For E. toriterminalis, the presence of ventral and anterior extratriangular segments indicates a bias towards Ceratoikiscidae, even if the aspect of stratigraphic continuation is overlooked. Etymalbaillella toriterminalis is relatively small in dimensions when compared to E. renzii. It is distinguished from E. yennienii by having longer maximum lengths for wings.

\section{Etymalbaillella renzii $\mathrm{Li}, 1995$}

Figure 11.10

1995 Etymalbaillella renzii Li, p. 338, pl. 1, figs. 1, 3, 5.

Holotype.-Neotype specimen no. SEES/140703-49-ER1 (Fig. 11.10) from Sandbian limestone beds in the Pingliang Formation, Guanzhuang section, Gansu Province, China.

Diagnosis.-Conical skeleton composed of a latticed framework supported by and merged into the three-rod ceratoikiscid architecture; intersector, a-bar, and b-bar. Downward-facing pair of wings extends from the upper section of the intersector and a-bar. Emended from Li (1995).

Description.-Conical lattice frame is at least $300 \mu \mathrm{m}$ long, excluding the broken apex of the specimens. The anterior end is wide open with $\varnothing=112 \mu \mathrm{m}$. The apical section of the shell develops a pair of identical wing-like projections, facing downward, having an approximate length of $50 \mu \mathrm{m}$. The rest of the shell is devoid of wings, unlike E. toriterminalis and E. yennienii. Pores are polygonal and gradually reduce in size upon reaching the posterior section of the shell. Pore sizes at the anterior end are larger than those seen in other species of Etymalbaillella.

Remarks.-A single specimen was recovered from the Pingliang Formation in the Guanzhuang section. The original type material (BGIN 930919) has been destroyed (Li Hongsheng personal communication, 2020, via Luo Hui), so a neotype (SEES/140703-49-ER1) is designated herein. The specimen is moderately well preserved and SEM observations are not of sufficient clarity to allow commenting on the initial skeleton configuration. Nevertheless, the presence of identical apical protrusions and a conical lattice frame allows confident identification. The emended diagnosis of the species is based on the initial skeletal details revealed through the micro-CT model constructed for E. toriterminalis and the SEM observations of E. renzii.

Genus Gansuceratoikiscum Wang, Cheng, and Zhang, 2010

Type species.-Gansuceratoikiscum guanzhuangensis Wang et al., 2010 (pl. 1, fig. 11) from Pingliang Formation in the Guanzhuang section of the Gansu Province, China by original designation.

Gansuceratoikiscum guanzhuangensis Wang, Cheng, and Zhang, 2010

Figure 12.1-12.5

1991 Ceratoikiscum sp. 1; Wang, p. 249, pl. 1, figs. 6, 7.

2010 Gansuceratoikiscum guanzhuangensis Wang et al., p. 475 , pl. 1, figs. 1-30.

Holotype.-Specimen in Wang et al. (2010, pl. 1, fig. 11) from limestone beds in the Pingliang section, Gansu Province, China.

Description.-Specimen 1 in Figure 12 appears to have the patagial tissue, a-bar, and b-bar, while specimens in Figure 12.3 and 12.4 display different numbers of caveal ribs originating from the a-bar. The specimen in Figure 12.2 could be a juvenile form with all three rods, a row of arch, and a median bar (sensu Wang et al., 2010).

Remarks. - Specimens recovered are most likely to be fragments of G. guanzhuangensis. Proholoeciscus foremanii reported from Qilian Mountains, China (Li, 1995), which is now regarded as a nomina dubia (Noble et al., 2017), may also be a fragment of G. guanzhuangensis because it appears similar to the specimen in Figure 12.3.

Order Entactinaria Kozur and Mostler, 1982

Family Haplentactiniidae Nazarov in Nazarov and Popov, 1980 (nomen translatum Nazarov and Ormiston, 1984)

Genus Bissylentactinia Nazarov, 1975 
Type species.-Bissylentactinia rudicula Nazarov, 1975 (GIN. No. 4046-19) from the Egindinskaya series, Southern Urals, Northern Mugodzhars, Aitpaika River by original designation.

\section{Bissylentactinia bifida Nazarov and Popov, 1980} Figure 12.11

1980 Bissylentactinia bifida Nazarov in Nazarov and Popov, p. 64 , pl. XV, fig. 2.

Holotype.-Specimen (GIN 4333/22) from the Middle Ordovician, Bestamaksk Formation, SW foothills of Chingiz Range, eastern Kazakhstan (Nazarov and Popov, 1980, pl. XV, fig. 2).

Remarks.-The specimen encountered clearly demonstrates 'grouped branching' developing at a certain distance from the median point, which distinguishes this genus from other members of the Palaeoscenidiidae. Because the studied assemblage includes several fragments of members belonging to the Palaeoscenidiidae, identification of Bissylentactinia would be challenging, if not for the grouped apophyses. The type specimen of B. bifida illustrated by Nazarov and Popov (1980) differs from the material in this study in having slightly longer $(224 \mu \mathrm{m})$ spines. The specimen illustrated does not fully capture the length of the two hetero-polar spines. Apophyses on two spines are also broken. This is the first report of B. bifida from the Ordovician since erection of this species by Nazarov and Popov (1980). The long stratigraphic gap existing between Darriwilian (Nazarov and Popov, 1980) and Frasnian (Nazarov, 1975) occurrences can now be reconciled with the intervening occurrence in the Sandbian reported herein.

\section{Genus Haplentactinia Foreman, 1963}

Type species.-Haplentactinia rhinophyusa Foreman, 1963 (USNM 640392) from the Norwalk 1 calcareous concretions of the Upper Devonian Huron Member of the Ohio Shale by original designation.

Haplentactinia baltica Nazarov in Nazarov and Nolvak, 1983 Figure 5, Supplemental Data 2

1980 Haplentactinia sp. Nazarov in Nazarov and Popov, p. 55, pl. XVII, fig. 4.

1983 Haplentactinia baltica Nazarov in Nazarov and Nolvak, p. 5, pl. II, figs. 2-4.

Holotype.-Specimen (GIT 182-4), former no. GIN R2/5408, from the Upper Ordovician, Saunja Formation in Estonia (Nazarov and Nolvak, 1983, pl. II, figs. 2-4).

Description.-Micro-CT observations on specimen SEES/ 140703-55-HB1 reveal a clearly discernible outer shell, eccentrically positioned inner shell, and six primary spines that originate from the latter (Fig. 5.1). The point of origination of one of the spines cannot be clearly determined. The outer shell is polygonal and made of an irregular lattice developing from apophyses of the primary spines. Apophyses develop at variable distances from the inner shell and are interconnected laterally and obliquely, producing an intertwined mesh. Because of these interconnections, wide sub-circular and polygonal-shaped spaces $(\varnothing \approx 20 \mu \mathrm{m})$ develop on the outer shell (Fig. 5.3). The maximum outer shell $\varnothing \approx 138 \mu \mathrm{m}$. The inner shell is made of delicate 'bandages' (sensu Won and Iams, 2011) and cylindrical strands of varying thicknesses coalescing to form a spheroid with a maximum $\varnothing=45 \mu \mathrm{m}$ (Fig. 5.2). The lengths of gently tapering spines vary between $80-140 \mu \mathrm{m}$. Slightly curved or straight spines are both present.

Remarks. - The inner spicule mentioned in the species description of Nazarov and Nolvak (1983) was not observable in our scanned specimen. However, the inner shell is composed of thin cylindrical strands, which might be easily confused with a spicule. Only one specimen was found and the fair probability of the inner spicule not being preserved in it prevents further revision to the systematics of the species. The first encounter of this species is from the Ulkuntas Member, which is Hirnantian in age (Nazarov and Popov, 1980; Aitchison et al., 2017a). The Saunja Formation of Estonia where the type specimen was introduced is of Nabala Stage and coincides with the uppermost Sandbian. Although $H$. baltica was apparently a rare species in the Late Ordovician, the distribution in three isolated paleo-plates (Baltica, N. China, and Kazakh) terranes accounts for its successful dispersal.

Family Palaeoscenidiidae Riedel, 1967

Genus Palaeoephippium Goodbody, 1986, sensu MacDonald, 2004

Type species.-Palaeoephippium bifurcum (UA 7155) from the Cape Phillips Formation type section, Cornwallis Island, N.W.T, Canada (Goodbody, 1986, pl. 4, figs. 1-4).

\section{Palaeoephippium radices Goodbody, 1986, sensu MacDonald, 2004 \\ Figure 12.6, 12.9, 12.10}

1986 Palaeoephippium radices Goodbody, p. 144, pl. 4, figs. 9-12.

1994 Palaeoephippium radices; Li, p. 266, pl. 2, fig. 6.

1995 Palaeoephippium radices; Amon et al., p. 6, text fig. 7.

2004 Palaeoephippium radices; MacDonald, p. 271, figs 5.1-5.4, 8.1-8.4.

Holotype.-Specimen (UA 7166) from the Cape Phillips Formation, Cornwallis Island, N.W.T, Canada (Goodbody, 1986, p. 144, pl. 4, figs. 9, 10).

Description.-Six rays, three from each end of a median bar. One apical ray, one intermediate ray, and one basal ray positioned at each end, bifurcating at short distances from the median bar. All six rays terminate with sharp ends.

Remarks.-One nearly complete specimen (Fig. 12.10) was encountered, together with several bifurcated fragments. Although Li (1995) mentioned this genus on an occurrence chart, no figures or descriptions were provided. 


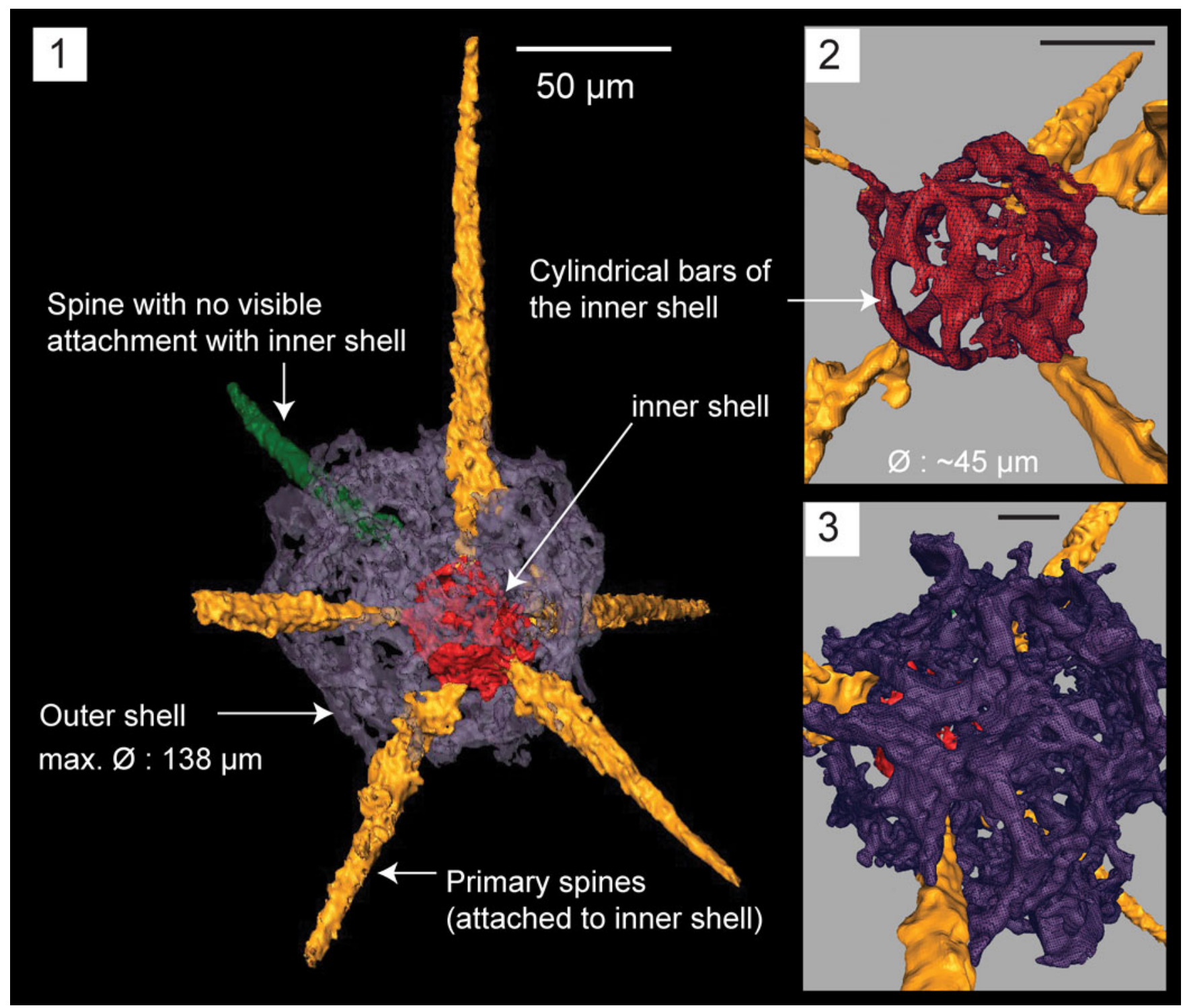

Figure 5. Structural details highlighted using a micro-CT model for Haplentactinia baltica (SEES/140703-55-HB1). (1) Complete specimen; (2) inner shell with five spines attached; (3) lattice meshwork of the outer shell. Scale bars (1) $50 \mu \mathrm{m} ;(\mathbf{2}, \mathbf{3}) 25 \mu \mathrm{m}$.

Palaeoephippium spp.

Figure 12.7, 12.8

Remarks.-Species level identification is not possible because the specimens are highly fragmentary. However, spines with point- or bar-centered apical, intermediate or basal distribution, and subsequent bifurcation are most likely to be associated with Palaeoephippium. There is a close resemblance between the specimen (Fig. 12.8) and P. tricorne Goodbody illustrated in Goodbody (1986, fig. 6.1), which illustrates a fragment, indicating Figure 12.8 could also be $P$. tricorne. The specimen in Figure 12.7 has six rays, one of which is apical. Three short rays occupy an intermediate position, and the remaining two basal rays bifurcate at least twice before terminating with pointed ends. The intersection of these six rays is at a point rather than a median bar.
Family Pylentonemidae Deflandre, 1963

Genus Protopylentonema new genus
Type species.-Protopylentonema ordosensis n. gen. n. sp. (SEES/140703-49-PO1) from the Pingliang Formation in the Guanzhuang section,, Gansu Province, China.

Diagnosis.-Pylomate radiolarian with an initial skeleton in the form of five rays arranged in two nearly perpendicular planes. One regularly porous sub-spherical shell envelopes the rays. Rays may develop apophyses midway that coalesce to form a second perforated shell. A few thin beams originate from the second shell to penetrate the cortical shell as short or long conical spines. Simple circular pylome is positioned near one or two of the primary spines. Primary and secondary spines often develop buttresses on cortical shell. Few to numerous conical by-spines. 
Occurrence.-Darriwilian to Sandbian from Kazakhstan and China (Nazarov, 1975; Nazarov et al., 1975; Nazarov and Popov, 1980; Wang, 1993; herein).

\section{Etymology.-In the sense of 'Primitive Pylentonema'}

Remarks._Protopylentonema $\mathrm{n}$. gen. is introduced in this study to include Ordovician pylomate forms possessing a distinctive spicular system that represent entactinarians. Constituent species include Protopylentonema insueta (Nazarov, 1975), Protopylentonema aperta (Nazarov et al., 1975), Protopylentonema rimata, (Nazarov and Popov, 1980), and Protopylentonema ordosensis n. sp.. The original species descriptions for $P$. aperta, $P$. rimata, and $P$. insueta clearly state the presence of centrally positioned, nearly perpendicularly arranged five spines and in the case of $P$. rimata and $P$. insueta, the existence of a vague inner shell developed from apophyses (Nazarov, 1975; Nazarov and Popov, 1980). These features accord with the micro-CT model created for $P$. ordosensis; the type species of the new genus. Nazarov and Ormiston (1993) reassigned these species $(P$. aperta, $P$. rimata, and $P$. insueta) to the genus Cessipylorum. Subsequently, Noble and Webby (2009) revised the genus Cessipylorum and synonymized it with Kalimnasphaera. Micro-CT comparison of Protopylentonema ordosensis n. sp. and Kalimnasphaera pingliangensis $\mathrm{n}$. sp. demonstrates this assignment is not appropriate and that the taxa described earlier by Nazarov (1975) and Nazarov and Popov (1980) are best placed within the new genus Protopylentonema.

\section{Protopylentonema ordosensis new species} Figures 6, 11.13

1993 Inanihella penrosei Wang, pl. 3, fig. 1.

1993 Cessipylorum cf. aperta Wang, pl. 4, figs. 7, 8.

Holotype.-Specimen no. SEES/140703-49-PO1 (Fig. 11.13) and paratype SEES/140703-49-PO2 (digitized as Fig. 6 and Supplementary Data 3) in the micropaleontology collection of SEES-UQ. Known from Sandbian limestone beds in the Pingliang Formation, Guanzhuang section, Gansu Province, China.

Diagnosis.-Pylentonemid radiolarian consisting of two sub-spherical shells and a five-rayed initial spicule; two bi-polar rays and three rays lying in a nearly perpendicular plane. All five rays pass through the two shells to form long tapering primary spines with buttresses on outer shell. One bi-polar ray, emerging as a primary spine, guards the circular pylome. Three secondary spines initiate at the inner sphere and form buttresses upon penetrating the outer shell. Few by-spines originate at the surface of the outer shell.

Occurrence.-Sandbian from China (Wang, 1993, and herein).

Description.-Skeleton consists of two sub-spherical shells. Outer shell $(\varnothing=285 \mu \mathrm{m})$ comprises a regularly porous network with circular pores $(\varnothing, 5-15 \mu \mathrm{m})$ (Fig. 6.5). Pore frames maintain a consistent thickness $(5 \mu \mathrm{m})$, except at junctions and in the vicinity of spines. The initial skeleton consists of five rays that lie upon two nearly perpendicular planes. Two of the five rays are bi-polar and positioned on one plane. Three of the five rays are arranged on a plane nearly perpendicular to the other (Fig. 6.8). The micro-CT scan did not reveal the exact structure of the meeting point (sensu Won and Below, 1999) because secondary infillings occupied the site. An element rendered partially transparent that is illustrated in Figure 6.8 shows a polyhedron floating at the middle of five rays. When the rays are projected inwards, two sets of rays create separate articulation points, suggesting the possibility of the presence of an intervening bar (Fig. 6.3). This feature is short and fits the definition of a micro-bar (sensu Won and Below, 1999). Approximately $65 \mu \mathrm{m}$ from the meeting point, rays develop apophyses that coalesce to form the delicate inner shell $\varnothing=125 \mu \mathrm{m}$ (Fig. 6.1). The shell is sub-spherical and unevenly perforated with polygonal rims developed around pores of varying sizes. Rays attain a wider $\varnothing$ before they grow beyond the inner shell. They convert to beams $(\varnothing=15 \mu \mathrm{m})$ and rise to the surface of the outer shell. A set of three thinner beams $(\varnothing=7-8 \mu \mathrm{m})$ initiates from pore-frame junctions of the inner shell (Fig. 6.1). These secondary beams also penetrate the surface of the external shell. Primary and secondary beams that convert to spines branch trichotomously or quadrachotomously just before interception with the outer shell (Fig. 6.7) and develop massive buttresses on the surface after penetration (Fig. 6.6). This imposes a slightly hexagonal shape to the outer shell as the six massive buttresses develop on the sphere (Fig. 6.5). The primary and secondary spines cannot be differentiated after surfacing and develop into distally tapering spines with lengths subequal to or slightly less than the shell $\varnothing$. Average $\varnothing \approx 45 \mu \mathrm{m}$ near the base of a spine. The pylome $(\varnothing=55 \mu \mathrm{m})$ is generally sub-circular and has no rim (Fig. 6.2). It develops near one of the bi-polar rays that grows into a main spine. Since the pylome is commonly regarded as the posterior end of protozoans, the opposing main spine can be referred to as an apical spine (see Fig. 6.4). Very few short $(35 \mu \mathrm{m})$, conical by-spines occur on pore frame junctions of the outer shell.

Etymology.-Named after the Ordos Basin, in which sediments of the Pingliang Formation were deposited.

Remarks.-A micro-CT model demonstrates the role of the initial skeleton in creating the two shells. Because the model does not reveal the structure of the meeting point of rays, there is a possibility of having a point-centered, five-rayed spicule or a polyhedron (sensu Nazarov and Popov, 1980) instead of the micro-bar. Nazarov et al. (1975) preferred the words 'polyhedron' and 'hexahedron' to describe the center structure of $P$. aperta and $P$. insueta. The number of secondary spines that develop on the inner or external shell along with shell dimensions can be used to differentiate between species of this genus, while five primary spines will be a constant.

Order Spumellaria Ehrenberg, 1876

Family Haplotaeniatidae Won, Blodgett, and Nestor, 2002 Genus Haplotaeniatum Nazarov and Ormiston, 1993 


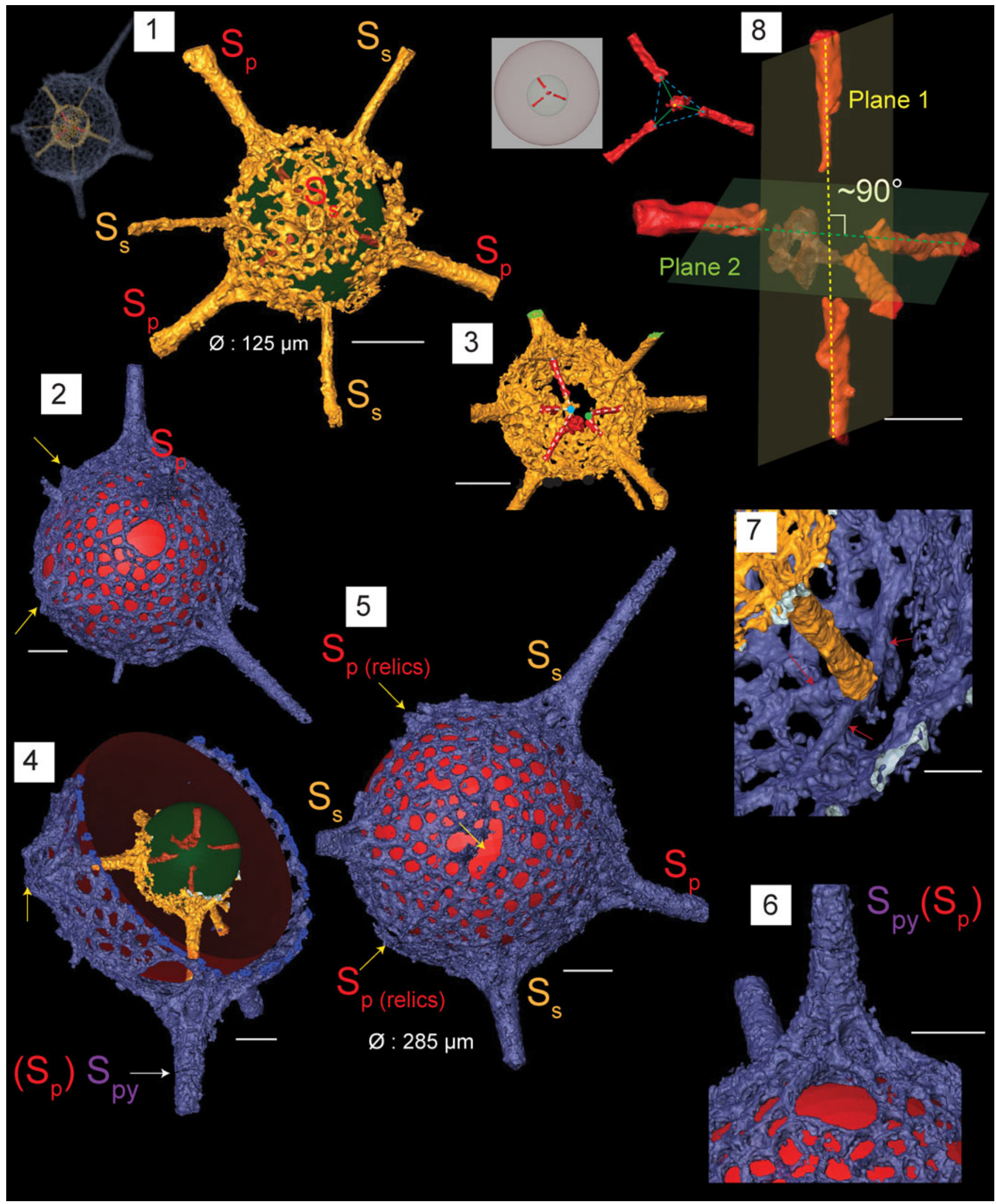

Figure 6. Structural details highlighted using micro-CT model for Protopylentonema ordosensis n. sp. (paratype, SEES/140703-49-PO2). S $\mathrm{S}_{\mathrm{P}}$ : primary spines initiating from initial spicule. $\mathrm{S}_{\mathrm{S}}$ : secondary spines initiating from inner sphere. $\mathrm{S}_{\mathrm{Py}}$ : spines associated with pylome. Red and green spheres are inserted to aid visualization; yellow arrows indicate relics of SP. (1) Inner sphere and distribution of primary spines $\left(\mathrm{S}_{\mathrm{P}}\right)$ and secondary spines $\left(\mathrm{S}_{\mathrm{S}}\right)$ relative to the initial skeleton; $(2)$ structure of pylome; $(\mathbf{3})$ five rays displaying two separate meeting points; $(\mathbf{4})$ position of pylome; $(\mathbf{5})$ surface orientation of primary and secondary spines imposing a hexagonal appearance to the shell; (6) buttressed primary spine located near pylome; (7) branching of spines at the intersection with outer shell; red arrows indicate quadrachotomous branching possibly with one branch broken; (8) initial skeleton showing five-rayed spicule arranged along two nearly perpendicular planes. Scale bars are (1-6) $50 \mu \mathrm{m} ;(\mathbf{7 , 8}) 25 \mu \mathrm{m}$. 


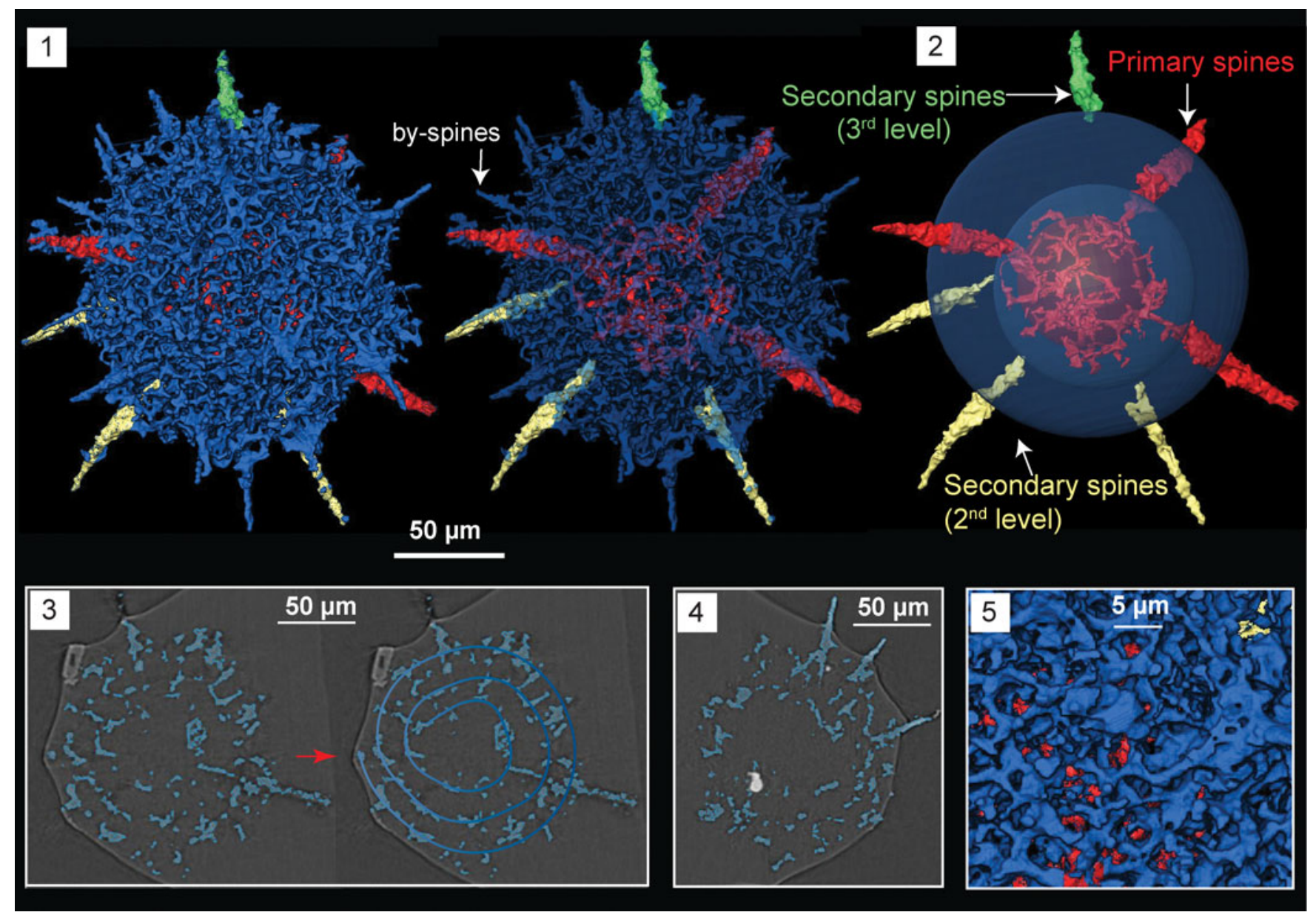

Figure 7. Structural details highlighted using micro-CT model of Haplotaeniatum implexa $\mathrm{n}$. sp. (SEES/140703-55-HI2), paratype. Red and green spheres are inserted to aid visualization. (1) Complete skeleton; (2) configuration of spines and the layers from which they originate; (3) original micro-CT image and the interpreted spiraliform arrangement of layers; (4) growth of secondary spines from the mesh; (5) pseudospongy mesh of the outer shell surface. Scale bars are (1-4) $50 \mu \mathrm{m}$; (5) $5 \mu \mathrm{m}$.

Type species.-Haplotaeniatum labyrintheum Nazarov and Ormiston, 1993 (GIN 4679/33) from the Sakmarskaya Suite, Southern Urals by original designation.

\section{Haplotaeniatum implexa new species} Figures 7, 11.8

Holotype.-Specimen no. SEES/140703-55-HI1 (Fig. 11.8) and paratype SEES/140703-55-HI2 (digitized as Fig. 7 and Supplemental Data 4) in the micropaleontology collection of SEES-UQ. Known from Sandbian limestone beds in the Pingliang Formation, Guanzhuang section, Gansu Province, China.

Diagnosis. - Haplotaeniatumidae characterized by numerous spines emanating from a dense, pseudospongy outer shell made of more than two spirally arranged discontinuous layers around an eccentric proloculus. Three tapering spines directly originate from the proloculus while the secondary spines initiate subsequently from the layers developing at different levels from the apophyses of the primary spines. Several thin by-spines occupy the outer surface.
Occurrence.-Sandbian from China (herein).

Description.-The spherical skeleton of $H$. implexa revealed by micro-CT observations constitutes a small proloculus overlain by a pseudospongy mesh composed of few incomplete layers arranged in a vague spiraliform configuration (Fig. 7.3). At least two levels existing in the entangled meshwork exposed when the points of origin of a few secondary spines were projected back using a digital model. Slightly eccentric proloculus $(\varnothing=62 \mu \mathrm{m})$ is made of thin bars that coalesce to form an approximately spherical shape. Consequently, large polygonal spaces appear on the proloculus surface. Three of the numerous spines emanating from the outer shell originate directly from the proloculus (Fig. 7.2). They are approximately arranged in a single plane and have a $\varnothing=15 \mu \mathrm{m}$ at the base where they penetrate the outer surface. They develop apophyses that subsequently give rise to discontinuous layers of meshwork (Fig. 7.4). The layers themselves produce secondary spines of slightly lesser base $\varnothing=8-13 \mu \mathrm{m}$. Pseudospongy outer shell develops small pores up to $\varnothing=5 \mu \mathrm{m}$ (Fig. 7.5) and several by-spines with lengths up to $40 \mu \mathrm{m}$. The average outer shell $\varnothing=180 \mu \mathrm{m}$ (Fig. 7.1). All spines taper distally imposing a thorny appearance to the entire specimen. 
Etymology.-From the Latin 'implexa' symbolizing the 'entangled.'

Remarks.-Micro-CT reveals that layers of H. implexa are not as widely spread as those of Haplotaeniatum albaensis Perera, Aitchison, and Nothdurft, 2020 (see Perera et al., 2020). All the spherical Haplotaeniatum species encountered from the Darriwilian Shundy Formation (Pouille et al., 2014) are larger in outer diameter compared to H. implexa. However, it closely resembles the disorderly interwoven mesh of Haplotaeniatum sp. B (Pouille et al., 2014) and both share numerous outer spines. Haplotaeniatum sp. B is distinguished from $H$. implexa by its larger $\varnothing=313-320 \mu \mathrm{m}$ and wider spine bases $(\varnothing=20-25 \mu \mathrm{m})$. The thin spines and their bases differentiate Haplotaeniatum sp. C (Pouille et al., 2014) from $H$. implexa, although the spongy meshwork of both appears similar. The shell dimensions of Haplotaeniatum sp. A (Yi et al., 2018) apparently matches with our specimen, but is too poorly preserved to comment further. Because the spiraliform pattern seen in $H$. implexa is less prominent, the origination points of spines can be traced to locate the exact positioning of levels in the spiraliform arrangement (see Fig. 7.2). The initial diagnosis of Haplotaeniatum only incorporated species with spiraliform or concentric shells (Nazarov and Ormiston, 1993). However, subsequent revisions to the genus by Won et al. (2002) included species with a labyrinthine arrangement ranging between distinctly layered to entirely non-layered. The specimen encountered can be confidently placed within Haplotaeniatum and the micro-CT model provides insight into the microstructure of the genus.

Family Inaniguttidae Nazarov and Ormiston, 1984, sensu Noble, 1994, sensu Danelian and Popov, 2003 Genus Geminusphaera new genus

Type species.-Geminusphaera kongtongensis $\mathrm{n}$. sp. (SEES/ 140703-55-GK1) from the Pingliang Formation, in the Guanzhuang section Gansu Province, China.

Diagnosis.-Inaniguttid radiolarians possessing two porous spherical shells and seven or more radially arranged primary spines originating from the inner sphere. Usually accompanied by several by-spines.

Occurrence.-Sandbian from China (herein).

Etymology.-Derived from Latin, 'geminus-sphaera' meaning 'double-sphere.'

Remarks.-Hitherto, generic classifications of members of the Inaniguttidae are based on a wide range of morphological features, including the number of spines, number of spheres, spacing between spheres, and their dimensions (Caridroit et al., 2017; Noble et al., 2017). The significance assigned to each of these aspects is still debated because some authors question their reliability after considering factors such as ontogeny and ecological stress (Noble and Aitchison, 1995; Danelian and Popov, 2003; Suzuki, 2006; Maletz, 2011; Trubovitz and Stigall, 2018; Kachovich and Aitchison, 2020). Micro-CT observation reveals the genus Geminusphaera n. gen. shares characteristics intermediate between Inanihella and Inanibigutta. Inanihella incorporates inaniguttids with two closely spaced porous spheres bearing numerous spines. The diagnosis of Inanihella further mentions the existence of an inner structure in the form of a spheroid $(\varnothing=45-55 \mu \mathrm{m})$ or its modification. This represents the initial skeleton of Inanihella. In addition, it is flexible toward forms with pylomes and furrowed main spines (Nazarov and Ormiston, 1984; Nazarov, 1988; Noble et al., 2017). All these diagnostic features appear to be more compatible with Silurian morphotypes than those from the Ordovician (Nazarov and Ormiston, 1984, 1993; Siveter et al., 2007). However, several authors have assigned a few Ordovician species under Inanihella despite poor preservation that hinders precise identification. Inanihella (?) akzhala (Danelian and Popov, 2003) and I. bakanasensis Danelian and Popov, 2003 (reported by Danelian and Popov, 2003, and Maletz et al., 2009) do not show any trace of an inner structure within the inner sphere. Inanihella penrosei (Ruedemann and Wilson, 1936) described by Wang (1993) from the Pingliang Formation clearly shows the presence of a spheroid within the inner shell although the two spheres are not closely spaced as is typically seen in Silurian forms. Pouille et al. (2013) assigned five species under Inanihella, of which only two have a spherical internal structure located within the two shells. Although the aforementioned encounters comply with the expected shell dimensions for Inanihella, the presence of an internal structure should be favored because it represents the initial skeleton. Failure to observe an initial skeleton because of poor preservation also suggests the possibility of the non-existence of any internal structure. Maletz and Bruton (2008) suggested the possibility of resorbing materials from inner spheres to form outer spheres during ontogeny. Meanwhile, Inanibigutta (Nazarov, 1988) only recognizes two-sphered inaniguttids, with only six primary spines. Unlike Inanigutta, the number of spines on Inanibigutta is fixed (Noble et al., 2017). The new genus Geminusphaera includes inaniguttids that are constructed from two distinct porous spheres and have seven or more primary spines.

Previous reports.-Maletz and Bruton (2008) reported an assemblage of 51 specimens that included inaniguttids with two to three spherical walls connected by beams and variable numbers of outer spines, which they referred to as Inanigutta sp. B. They suggested a revision to the Inaniguttidae, allocating all spumellarians with multiple spheres and spines under Inanigutta. Maletz and Bruton (2008, fig. 9F, G) illustrated two wellpreserved specimens with two distinct spheres and multiple spines that could be incorporated within Geminusphaera n. gen. In these specimens, inner and outer sphere $\varnothing=140 \mu \mathrm{m}$ and $70 \mu \mathrm{m}$, respectively, and the number of spines varies from 8-10. The description of characteristics of the mesh and the origination of spines are analogous to those of Geminusphaera n. gen., suggesting assignment to the new genus is appropriate. In combination, this extends the possible stratigraphic range of Geminusphaera n. gen. to the Darriwilian.

Helioentactinia? bakanasensis reported by Nazarov (1975) from Arenigian strata of the Ushkyzyl Formation (Zhylkaidarov, 1999) was described from thin sections and has two shells and numerous spines. This material also could be allocated to the new genus because the sphere dimensions $(115-169 \mu \mathrm{m}$, 
86-131 $\mu \mathrm{m})$ and species description align best with Geminusphaera $\mathrm{n}$. gen. This would further extend the stratigraphic range of Geminusphaera n. gen. to at least the Lower Ordovician.

\section{Geminusphaera grandis new species}

Figure 11.11

Holotype.-Specimen no. SEES/140703-55-GG1 (Fig. 11.11) in the micropaleontology collection of SEES-UQ. Known from Sandbian limestone beds in the Pingliang Formation, Guanzhuang section, Gansu Province, China.

Diagnosis.-Two spherical shells connected by at least eight primary spines originating from the inner sphere. Outer shell has no by-spines.

Occurrence.-Sandbian from China (herein).

Description.-Spherical outer shell and inner shell show average $\varnothing=318$ and $125 \mu \mathrm{m}$, respectively. Two spheres are separated by a gap of $\sim 70 \mu \mathrm{m}$. Rounded to oval pores of varying sizes (8-24 $\mu \mathrm{m})$ cover the outer shell, while the inner shell pores are generally smaller. Primary spines start as beams with constant $\varnothing$ $\approx 13 \mu \mathrm{m}$ and traverse through the outer shell. All the primary spines are equal in length $(180 \mu \mathrm{m})$ and taper gradually before terminating with pointed ends. Maximum spine $\varnothing$ of $25 \mu \mathrm{m}$ is maintained at the surface intersection with the outer shell. Interpore frames and the bases of spines are attached smoothly through direct continuations.

Etymology.-From the Latin 'grandis' meaning large.

Remarks.-Previously, many double shelled, multiple spine bearing inaniguttids were assigned to the genus Inanihella, despite controversies discussed under genus remarks. This species is easy to distinguish from $G$. kongtongensis n. gen. n. sp. owing to its larger shell dimensions. In addition, pores of G. grandis n. gen. n. sp. are rounded to oval, whereas pores of G. kongtongensis $\mathrm{n}$. gen. n. sp. exhibit irregular shapes.

\section{Geminusphaera kongtongensis new species}

Figures 8, 11.7, 11.12

Holotype.-Specimen no. SEES/140703-55-GK1 (Fig. 11.12); SEES/140703-55-GK2 (digitized as Fig. 8 and Supplemental Data 5); and paratype, SEES/140703-55-GK3 (Fig. 11.7), in the micropaleontology collection of SEES-UQ. Known from Sandbian limestone beds in the Pingliang Formation, Guanzhuang section Gansu Province, China.

Diagnosis. - Inaniguttid radiolarians with two spherical latticed shells bearing $8-10$ tapering primary spines originating from the inner shell that penetrate out through the outer shell. Several short conical by-spines are present.

Occurrence.-Sandbian from China (herein).
Description.-Micro-CT observation reveals two concentric spherical shells joined through nine radial beams originating at the surface of the inner sphere (Fig. 8.2). Outer sphere average $\varnothing=175 \mu \mathrm{m}$ whereas the inner sphere averages $90 \mu \mathrm{m}$ (Fig. 8.3, 8.4). Where spines are not generated or penetrating, shell thickness is maintained at $\sim 6 \mu \mathrm{m}$. Both spheres display similar lattice framework with sub-circular to irregular-shaped pores with $\varnothing$ ranging from $6-15 \mu \mathrm{m}$ (Fig. 8.7, 8.8). Except at junctions, bars delimiting the pores of the outer sphere maintain a regular thickness $(4-5 \mu \mathrm{m})$, although this is inconsistent when it comes to the inner sphere. Two spheres are positioned $~ 35$ $\mu \mathrm{m}$ apart (Fig. 8.2). The scanned specimen has nine primary spines, but the number ranges from $8-10$. These primary spines originate at the surface of the inner sphere and rise as radial beams until they penetrate the outer sphere (Fig. 8.6). They gradually start to taper after piercing the outer surface and grow to a maximum length of $85 \mu \mathrm{m}$ (measured from the surface of outer sphere). The width of the primary spines is $\sim 15 \mu \mathrm{m}$ at their base, which equals the $\varnothing$ they maintain at the base of inner sphere. No apophyses are developed on the spines. Few short conical by-spines $<10 \mu \mathrm{m}$ are present on the outer shell surface. No trace of any internal structure beyond the inner shell.

Etymology.- - Named after the Kongtong District in China where the type locality is situated.

Remarks. - The specimens encountered are well preserved and abundant enough to be able to determine shell measurements with confidence. Although primary spines are radially arranged and suggest the possible presence of a centrally located structure (Fig. 8.5), the micro-CT model clearly shows the vacant inner shell and how beams have developed from the inner shell surface. Oriundogutta miscella miscella (Nazarov in Nazarov and Popov, 1980) reported from Pingliang Formation has similar dimensions $(140-180 \mu \mathrm{m})$ to the outer sphere of G. kongtongensis n. gen. n. sp. and a similar number of primary spines (8-12). Illustrations in Wang (1993) are light-microscopic images, and it is possible that an inner sphere was undetected during observations. In addition, both reports come from the same formation, which may mean that both morphotypes represent a single species.

Genus Inanibigutta Nazarov and Ormiston in Nazarov, 1988

Type species.—Entactinosphaera aksakensis Nazarov, 1975 (GIN 4333/1) from the Bestamak Formation, SW foothills of Chingiz Range, eastern Kazakhstan by original designation.

\section{Inanibigutta pinglianensis Wang, 1993}

Figure 11.1

1991 Inanibigutta pinglianensis Wang, p. 249, pl. 1, figs. 11, 12.

1993 Inanibigutta pinglianensis; Wang, p. 100, pl. 5, figs. 1-8, pl. 6, figs. 1, 4 .

2000 Inanibigutta pingliangensis [sic]; Song et al., p. 67, pl. 1, fig. 2. 


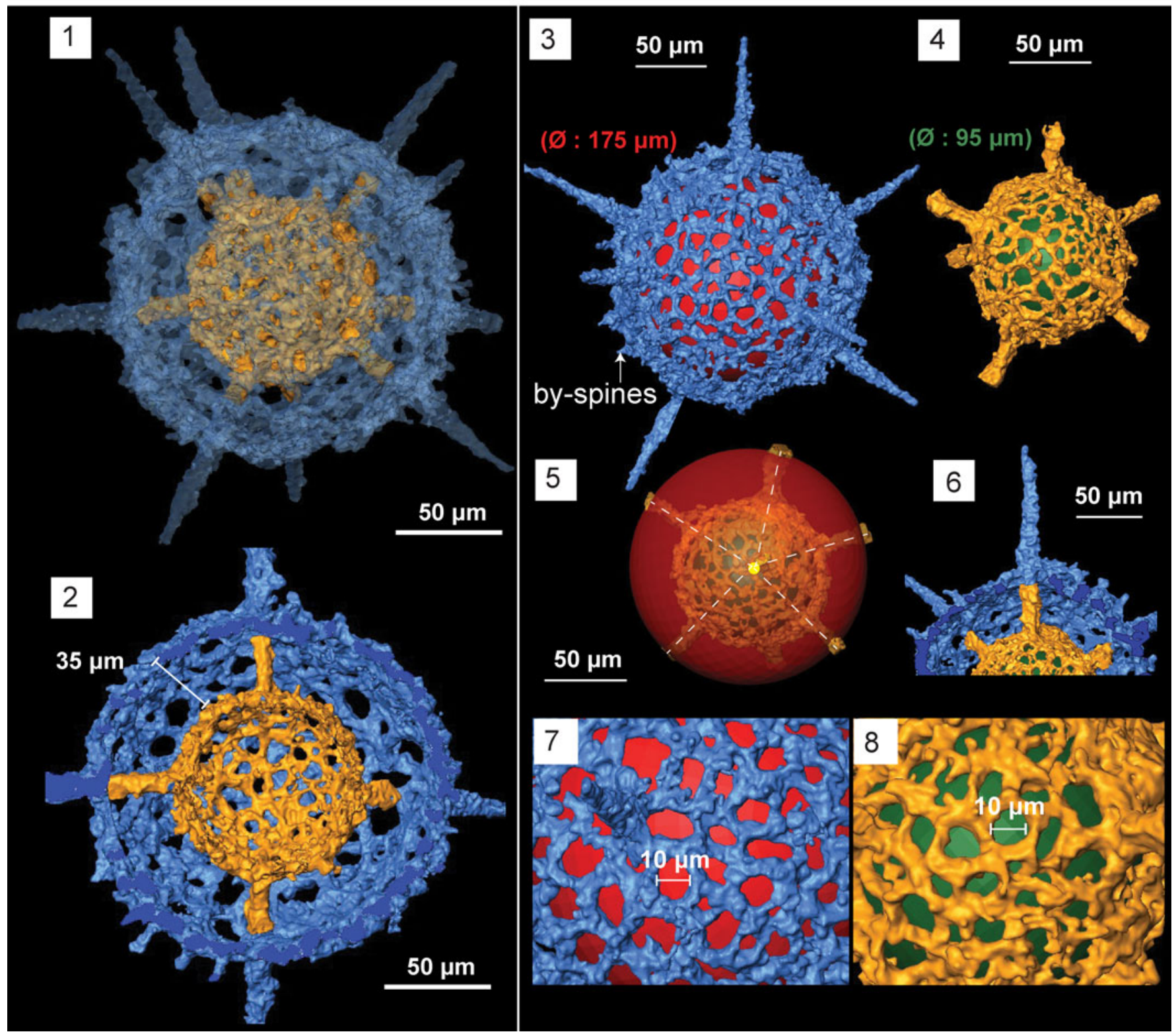

Figure 8. Structural details highlighted using micro-CT model of Geminusphaera kongtongensis $\mathrm{n}$. gen. n. sp. (SEES/140703-55-GK2). Red and green spheres are inserted to aid visualization. (1) Complete skeleton with nine spines; (2) cross-section showing the empty inner shell; (3) outer shell; (4) inner shell; (5) radial arrangement of spines; (6) spines penetrating the outer sphere; (7) lattice framework of the outer shell; (8) lattice framework of the inner shell. Scale bars are (1-6) $50 \mu \mathrm{m}$; $(\mathbf{7}, \mathbf{8}) 10 \mu \mathrm{m}$.

Holotype.-Specimen (NIGPAS-R0066) from Pingliang Formation, Gansu Province, China (Wang, 1993, pl. 5, fig. 2).

Remarks.-Specimens figured as Inanibigutta pingliangensis in Wang (1991), which were recovered from the Pingliang Formation, were illustrated and named but not accompanied by a species description. Wang (1993) again used probably the same specimen figured in his 1991 study, added some more specimens, and formally introduced s.l. pinglianensis with a name, proper species description, and a designated holotype.

Danelian and Popov (2003) tentatively assigned Inanibigutta pinglianensis to Triplococcus, assuming the bifurcated apophyses on the outer shell are relics of a third shell. However, the specimen illustrated in Figure 11.1 clearly shows the bifurcated apophyses cannot be extended as a third shell because these sets of apophyses do not grow equidistant from the outer shell on all six spines. Micro-CT models of Triplococcus in Kachovich and Aitchison (2020) demonstrate its unique morphology, allowing differentiation between the disputed forms. The structure inside the inner shell remains uncertain because all of the encountered specimens had an infilled interior. Co-occurring fossils and zircons (An et al., 1985; Wu et al., 2014; Yang et al., 2020) indicate that the Zhaolaoyu Formation in Shaanxi Province, from which I. pinglianensis was reported for a second time (Song et al., 2000), is Late Ordovician, likely Sandbian 
age. Therefore, I. pinglianensis can be regarded as a good Sandbian marker taxon, especially in shallow water facies.

\section{Inanibigutta verrucula (Nazarov and Popov, 1976)}

Figure 11.6

1976 Entactinosphaera verrucula Nazarov and Popov, p. 408, fig. $1 \mathrm{~d}$.

1980 Entactinosphaera verrucula; Nazarov and Popov, p. 38, pl. 3, fig. 6, pl. 11, fig. 6, text-fig. 17.

1988 Inanibigutta verrucula; Nazarov, fig. 31.

1993 Inanibigutta verrucula; Wang, p. 100, pl. 6, figs. 2, 3, 5-8.

1995 Inanibigutta verrucula; Li, p. 343, pl. 3, fig. 9.

1998 Inanibigutta verrucula; Danelian and Clarkson, p. 135, fig. $2 \mathrm{~g}$.

1999 Inanibigutta sp. cf. I. verrucula; Danelian, p. 630, fig. $4 \mathrm{H}$.

2000 Inanibigutta aff. vurracula [sic]; Song et al., p. 67, pl. 1, fig. 6.

2001 Inanibigutta (?) sp. O Danelian and Floyd, p. 493, fig. $4 \mathrm{~b}$.

?2020 Inanibigutta sp. cf. I. verrucula; Perera et al., p. 2039, pl. 1, fig. h.

Holotype.-Specimen (GIN 4333/18) from the Middle Ordovician, Bestamak Formation, SW foothills of Chingiz Range, eastern Kazakhstan (Nazarov and Popov, 1976, fig. 1d).

Remarks.-According to the original species description, one out of the six spines is generally lengthier than the rest. However, the closest specimens that displayed matching sphere dimensions did not show significant variation in spine length. In addition, none of the spines on the specimens maintains a constant $\varnothing$ throughout their length (Nazarov and Popov, 1976). Most spines on the observed specimens are broken at mid-length. Wang (1993) and Danelian and Clarkson (1998) reported $\varnothing=180-260 \mu \mathrm{m}$ and $131 \mu \mathrm{m}$ for outer sphere $\varnothing$, for which Nazarov and Popov (1976) reported $\varnothing=160-200 \mu \mathrm{m}$. Because inner and outer sphere dimensions of the observed specimens (average $\varnothing=74 \mu \mathrm{m}$ and $177 \mu \mathrm{m}$ ) correspond well with the measurements given in the original publication $(75-85 \mu \mathrm{m} ; 160-200 \mu \mathrm{m})$, and all five specimens encountered show similar dimensions, they are assigned to I. verrucula.

Genus Inanigutta Nazarov and Ormiston, 1984, sensu Nazarov, 1988

Type species._Entactinia unica Nazarov, 1975 (GIN 4333/2) from Bestamak Formation, SW foothills of Chingiz Range, eastern Kazakhstan by original designation.

Diagnosis.-Internal structure represented by a hollow, non-porous sphere $\varnothing=40-75 \mu \mathrm{m}$, rarely less, with four to six rays emanating from it at angles of $\sim 110-120^{\circ}$. A single, thick, mostly porous, envelope of up to $\varnothing=350 \mu \mathrm{m}$. Emended from Nazarov (1988).
Remarks.-Inanigutta was established to include species with a single shell, demonstrating six-spine geometry (Nazarov and Ormiston, 1984). However, the diagnosis was emended to include taxa with four to five spines by Nazarov and Popov (1980) who encountered two specimens with four-spine symmetry from an Upper Ordovician formation in Central Kazakhstan. Nevertheless, Inanigutta predominantly consists of six-spined species and no subsequent studies have reported forms with four/five spines.

\section{Inanigutta complanata (Nazarov) 1975} Figure 11.9

1975 Entactinia complanata Nazarov, p. 56, pl. XV, figs. 11, 12, pl. XX, figs 7,8 .

1980 Entactinia complanata; Nazarov and Popov, p. 29, pl. 1, figs. 2, 5, pl. 7, figs. 3, 4, pl. 11, figs. 3, 4, text-fig. 10.

1984 Inanigutta complanata; Nazarov and Ormiston, pl. IV, fig. 1.

?1992 Inanigutta cf. I. complanata Goto et al., p. 159, pl. 9, figs. 1-3.

1993 Inanigutta complanata; Wang, p. 99, pl. 10, figs. 1, 2.

2001 ?Inanigutta complanata Danelian and Floyd, p. 493, fig. $4 \mathrm{a}$.

2009 Inanigutta complanata; Noble and Webby, pl. 5, figs. 10, 11, pl. 6, fig. 14.

?2020 Inanigutta sp. cf. I. complanata; Perera et al., p. 2040, pl. 1, fig. i.

Holotype.-Specimen (GIN 4333/29) from the Middle Ordovician, Bestamak Formation, SW foothills of Chingiz Range, eastern Kazakhstan (Nazarov, 1975, pl. XX, fig. 8).

Remarks.-Shell dimensions given in Nazarov and Popov (1980) are clearer than those in Nazarov (1975). With the exception of Wang (1993), no subsequent reports correspond exactly with original descriptions (outer shell; $\varnothing=190 \mu \mathrm{m}$ and $175 \mu \mathrm{m}$, respectively, in Danelian and Floyd, 2001, and Noble and Webby, 2009). The dimensions given in Nazarov and Popov (1980) provide the basis for assignment of the observed specimens to $I$. complanata. Spine lengths of the studied specimens are slightly shorter, but the rest of the features align well within descriptions of Nazarov and Popov (1980). The structure of the initial skeleton from which the spines radiate is obscure.

Inanigutta gansuensis Wang, 1993

Figure 11.14

1993 Inanigutta gansuensis Wang, p. 99, pl. 7, figs. 1-8, pl. 8, figs. 1-11.

2013 Inanigutta gansuensis; Pouille et al., p. 1154, fig. 6.6.

2020 Inanigutta gansuensis; Perera et al., p. 2040, pl. 1, fig. d.

Holotype.-Specimen (NIGPAS-R0087) from the Middle Ordovician, Pingliang Formation, Gansu Province, China (Wang, 1993, pl. 7, fig. 1). 


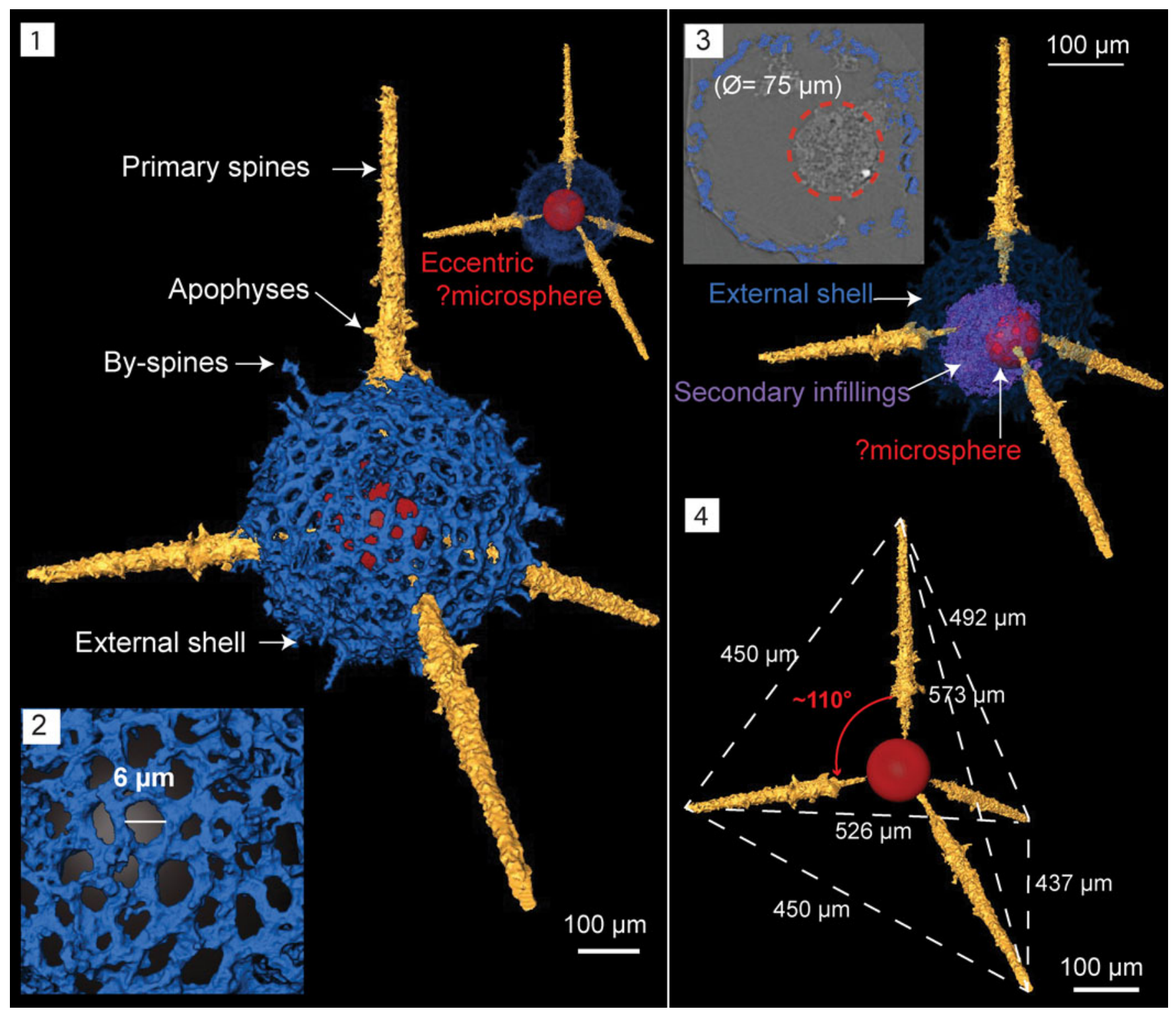

Figure 9. Structural details highlighted using micro-CT model of Inanigutta quadrispinosa n. sp. (paratype, SEES/140703-55-IQ2). Red sphere inserted to aid visualization. (1) Complete skeleton; (2) porous lattice of the outer shell; (3) ortho-slice showing the displaced ?microsphere and its present position within secondary infillings; (4) approximate tetrahedral arrangement and ?microsphere in its inferred original position. Scale bar is $100 \mu \mathrm{m}$ in $(\mathbf{1}, \mathbf{3}, \mathbf{4}) ; 6 \mu \mathrm{m}$ in $(\mathbf{2})$.

Remarks.-Although specimens in this study exhibit similar sphere dimensions, they seem to have more secondary spines than the type specimens of I. gansuensis Wang. However, this variation could be an artefact of SEM illustrations. No specimens have spine lengths $>300 \mu \mathrm{m}$, although Wang (1993) indicated a range of $200-500 \mu \mathrm{m}$.

\section{Inanigutta quadrispinosa new species}

Figures 9, 11.15

Holotype.-Specimen SEES/140703-49-IQ1 (Fig. 11.15) and SEES/140703-55-IQ2 (paratype, digitized as Fig. 9 and Supplemental Data 6) from Sandbian limestone beds in the Pingliang Formation, Guanzhuang section, Gansu Province, China.
Diagnosis.-Inaniguttid radiolarians constructed with a single perfectly spherical lattice shell and four primary spines arranged at $\sim 110^{\circ}$ to one another. Primary spines are directed towards a centrally located initial structure, possibly a microsphere. Numerous conical by-spines are located on external surface.

Occurrence.-Sandbian from China (herein).

Description.-Micro-CT observations reveal the structural configuration of this inaniguttid is exclusively constructed with four spines and a single shell. A perfectly spherical external shell averages $\varnothing=190 \mu \mathrm{m}$ and has a lattice arrangement with sub-circular to irregular-shaped pores (Fig. 9.1, 9.2). Maximum pore $\varnothing$ ranges between 5-20 $\mu \mathrm{m}$ 
(Fig. 9.2). The surface of the external shell is occupied by numerous short conical by-spines up to $25 \mu \mathrm{m}$ in length. Four rod-like primary spines with pointed tips penetrate the outer shell, maintaining an $\sim 110^{\circ}$ orientation to one another (Fig. 9.4). Primary spines originate from a slightly eccentrically located structure, perhaps a microsphere $(\varnothing=75$ $\mu \mathrm{m})$. Initial sections of spines lie within the shell with a $\varnothing$ lesser than the outer sections and point towards the center attaining a long conical shape (Fig. 9.4). The $\varnothing$ at the base of the primary spines on the shell surface is $20 \mu \mathrm{m}$ and they extend a further $190-220 \mu \mathrm{m}$.

Etymology.-From Latin 'quadrispinosa' referring to four spines.

Remarks. - The structure of the internal element is unclear, although it vaguely suggests the presence of a microsphere. On orthoslices, the microsphere is dislocated and engulfed by secondary infillings (Fig. 9.3). The external shell is undamaged. Dimensions of the taxon described are similar to Inanigutta gansuensis Wang reported from the Pingliang Formation in the Guanzhuang section, although the latter has six rather than four spines. Wang (1993) described $I$. gansuensis using light-microscopic images and some of the documented specimens appear to have four-spine geometry. Inanigutta gansuensis also had been reported in two studies where SEM images were used for descriptions (Pouille et al., 2013; Perera et al., 2020). Both studies mention broken spines and do not report any six-spined specimens.

\section{Genus Kalimnasphaera Webby and Blom, 1986}

Type species.-Kalimnasphaera maculosa Webby and Blom, 1986 (AM.F 134783) from limestone breccia deposits of the Malongulli Formation of New South Wales, Australia, by original designation.

Diagnosis.-Palaeoactinommid with a combination of either reticulate inner shell, porous medullary shell, and pylomate cortical shell or one double-layered reticulate inner shell and pylomate reticulate cortical shell enveloped in a loosely fenestrate outer shell preserved in varying degrees. More than three long, gently tapering, primary and secondary spines may originate from any level of the shell. Few to numerous by-spines occupy the space on cortical shell and between cortical and fenestrate shells if present. A fenestrate outer shell is only complete in areas where lateral spinules are linked to by-spines and main spines. Emended from Webby and Blom, 1986.

Remarks._Dunham and Murphy (1976) first reported Kalimnasphaera as 'sphaeroids' from Upper Ordovician calcareous concretions in Nevada. Material from that locality was revisited by Renz (1990) following a second encounter of the same genus from Upper Ordovician Australian limestones where it was formalized as Kalimnasphaera (Webby and Blom, 1986). Kalimnasphaera has been reported several times from Australia (Goto et al., 1992; Umeda et al., 1992; Noble and Webby; 2009), Kazakhastan (Pouille et al., 2013), and China (Cao et al., 2014), although the last account is questionable. Cessipylarum Nazarov in Afanasieva, (1986) and Cessipylorum Nazarov and Ormiston (1993) were later synonymized with Kalimnasphaera following revisions by Noble and Webby (2009), Pouille et al. (2013), and Noble et al. (2017). However, micro-CT scans of Kalimnasphaera indicate substantial differences between the skeletal architectures of Kalimnasphaera and the diagnosis provided for Cessipylorum.

\section{Kalimnasphaera pingliangensis new species} Figures 10, 11.4

1993 Inanihella penrosei Wang, p. 102, pl. 1, figs. 2-5, pl. 2, figs. $1-9$, pl. 3 , figs. 1,3 , pl. 4 , figs. 2,3 .

1986 Kalimnasphaera? sp. Webby and Blom, pl. 3, fig. 10, pl. 4, fig. 1.

Holotype.-Specimen no. SEES/140703-55-KP1 (Fig. 11.4) and paratypes SEES/140703-55-KP2 (digitized as Fig. 10 and Supplemental Data 7) and SEES/140703-55-KP3 in the micropaleontology collection of SEES-UQ. Known from Sandbian limestone beds in the Pingliang Formation, Guanzhuang section, Gansu Province, China.

Diagnosis. - Kalimnasphaerid lacking a fenestrate outer shell with few by-spines on the limited cortical shell surface. Pylomate cortical shell is perfectly spherical. Three primary spines originate directly from the inner reticulate microsphere and penetrate the single-layered medullary shell and cortical shell. The rest of the beams originate on the surface of the medullary shell and pass through the cortical shell forming secondary spines. At least six spines, including the three primary spines, develop buttresses on the cortical shell surface. Two secondary spines with simple bases guard a rimmed pylome on cortical shell.

Occurrence.-Sandbian to Katian from China (Wang, 1993, and herein) and Australia (Webby and Blom, 1986).

Description.-Observations using micro-CT reveal $K$. pingliangensis is exclusively constructed of three separate spheres interconnected by beams. The cortical shell $(\varnothing=325$ $\mu \mathrm{m})$ is porous, with sub-circular pores of $\varnothing$ ranging from 6-20 $\mu \mathrm{m}$ (Fig. 10.3). Pore frame maintains a consistent thickness, except in areas with secondary recrystallizations. Medullary shell $(\varnothing=120 \mu \mathrm{m})$ is centrally located within the cortical shell (Fig. 10.4). It is generally imperforate despite having regularly arranged elevated polygonal-shaped pore frames. Random perforations can be seen between pore frames, but it is not clear whether this is an original feature. The innermost initial skeleton $(\varnothing=44 \mu \mathrm{m})$ is constructed with thin bars coalesced to form a microsphere along with three rod-like beams merging with the medullary shell (Fig. 10.5). The position of this microsphere within the medullary shell is uncertain (it appears to be dislocated in the scanned specimen). Three beams emanating from the microsphere develop at $\sim 120^{\circ}$ to one another (Fig. 10.5). They traverse through the medullary shell and emerge from the cortical shell forming rod-like primary spines with massive buttresses, which extend up to $840 \mu \mathrm{m}$ in length 


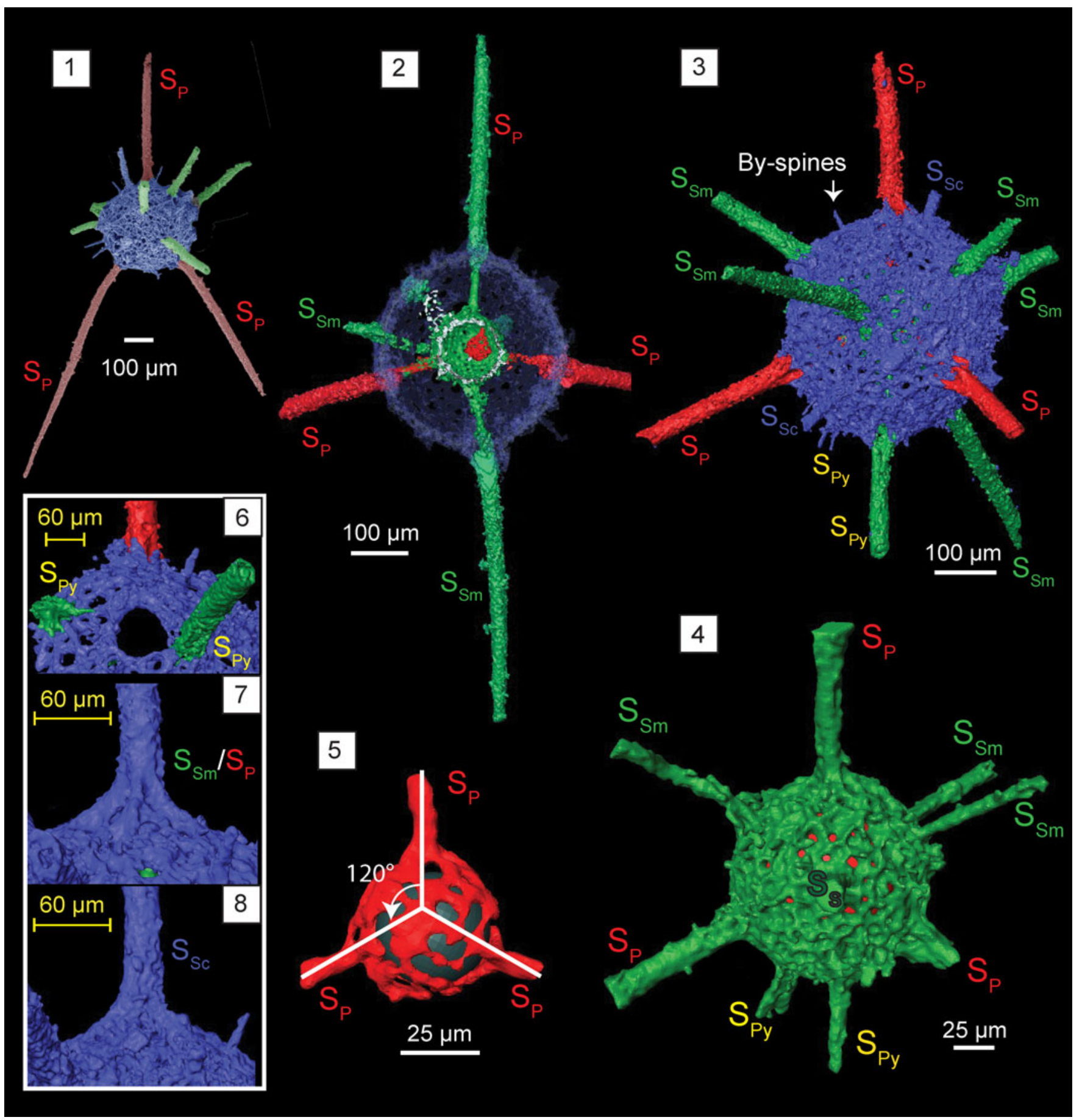

Figure 10. Structural details highlighted using micro-CT model of Kalimnasphaera pingliangensis n. sp. (paratype, SEES/140703-55-KP2). Sp: primary spines initiating from microsphere. $\mathrm{S}_{\mathrm{Sm}}$ : secondary spines initiating from medullary shell. $\mathrm{S}_{\mathrm{Sc}}$ : secondary spines initiating from cortical shell. $\mathrm{S}_{\mathrm{Py}}$ : secondary spines associated with pylome. (1) SEM image, colorized, corresponding to micro-CT images; (2) cross section showing the arrangement of three spheres; (3) cortical shell and types of spines; (4) medullary shell; $(\mathbf{5})$ microsphere and three primary spines $\left(\mathrm{S}_{\mathrm{P}}\right)$ originating from it (black sphere inserted to aid visualization); $(\mathbf{6})$ pylome and the two associated spines $\left(\mathrm{S}_{\mathrm{Py}}\right) ;(\mathbf{7})$ primary or secondary spines supported with buttresses; $(\mathbf{8})$ secondary spine $\left(\mathrm{S}_{\mathrm{Sc}}\right)$ with a simple base initiating from the cortical shell. Scale bars are (1-3) $100 \mu \mathrm{m} ;(\mathbf{4 , 5}) 25 \mu \mathrm{m} ;(6-8) 60 \mu \mathrm{m}$.

(Fig. 10.7). Medullary shell gives rise to three secondary spines that penetrate the cortical shell with buttresses and few other secondary spines that have no significant base on the cortical shell. One or two secondary spines with simple bases originate from cortical shell itself (Fig. 10.8). Both primary and secondary spines have no apophyses. They taper distally, but remain as rods of $\varnothing=30 \mu \mathrm{m}$ for most of their length. Some may bend slightly close to the base, while the rest are straight. Two secondary spines with regular bases are located in close proximity to the pylome, having a $\varnothing \approx 65 \mu \mathrm{m}$ and fringed with an elevated rim (Fig. 10.6). Several conical by-spines on the cortical shell surface extend up to $50 \mu \mathrm{m}$. 


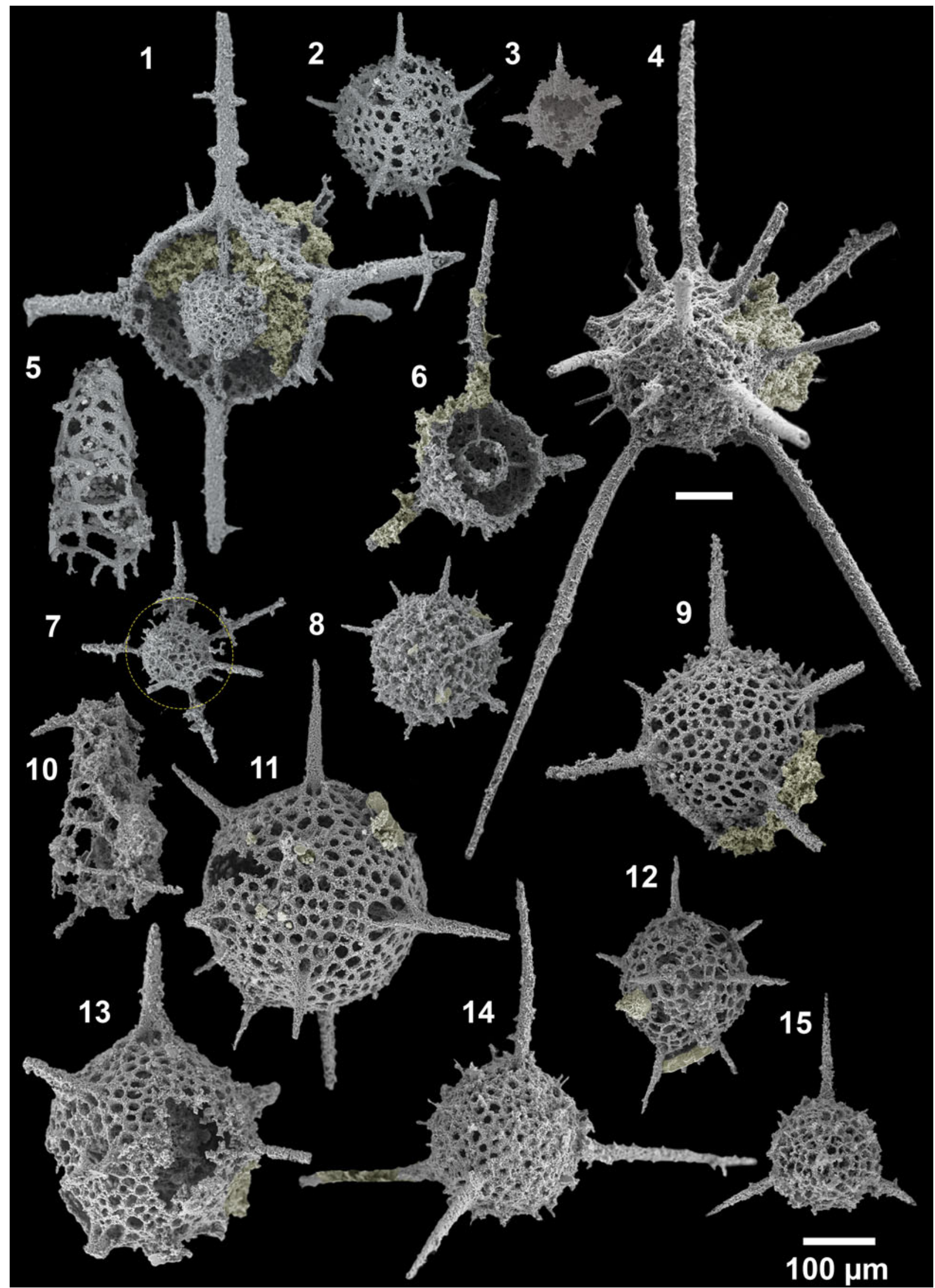


Figure 11. SEM images of radiolarians extracted from bed 5 of the Pingliang Formation, Guanzhuang section, Gansu, China. (1) Inanibigutta pinglianensis Wang, SEES/140703-55-IP1; (2) Oriundogutta bella Wang, SEES/140703-55-OB1; (3) ?Oriundogutta miscella minuta Wang, SEES/140703-55-OM1; (4) Kalimnasphaera pingliangensis $\mathrm{n}$. sp., holotype, SEES/140703-55-KP1; (5) Etymalbaillella toriterminalis Li, neotype, SEES/140703-55-ET1; (6) Inanibigutta verrucula (Nazarov and Popov), SEES/140703-49-IV1; (7, 12) Geminusphaera kongtongensis n. gen. n. sp., (7) SEES/140703-55-GK3, (12) holotype, SEES/ 140703-55-GK1; (8) Haplotaeniatum implexa n. sp., holotype, SEES/140703-55-HI1; (9) Inanigutta complanata (Nazarov), SEES/140703-55-IC1; (10) Etymalbaillella renzii $\mathrm{Li}$, neotype, SEES/140703-49-ER1; (11) Geminusphaera grandis $\mathrm{n}$. gen. n. sp., holotype, SEES/140703-55-GG1; (13) Protopylentonema ordosensis n. sp., SEES/140703-49-PO1; (14) Inanigutta gansuensis Wang, SEES/140703-55-IG1; (15) Inanigutta quadrispinosa n. sp., holotype, SEES/140703-49-IQ1. Scale bar is $100 \mu \mathrm{m}$.

Etymology.- Named after the Pingliang Formation in China, where the type locality is situated.

Remarks.-The species possesses a strong preservation bias compared to the rest of the assemblage. The absence of a fenestrate outer shell is characteristic because the primary, secondary, or by-spines had not developed apophyses to support lateral spinules as seen in $K$. maculosa. In addition, the medullary shell is not double-walled, as mentioned by Noble and Webby (2009). However, it should be noted that Webby and Blom (1986) recognized a "double walled medullary shell" as two separate shells with $\varnothing=13 \mu \mathrm{m}$ and $40 \mu \mathrm{m}$. Over 20 specimens with good preservation were observed and none provided evidence for the existence of a fenestrate shell. Because $K$. pingliangensis $\mathrm{n}$. sp. is a predecessor of $K$. maculosa, it is possible that the distinctly separate spheres seen in older forms may have combined at a later stage to form the double-walled, medullary-shelled morphotypes. However, Webby and Blom (1986, fig. 3.10) appears similar to $K$. pingliangensis, justifying its tentative assignment to $K$. maculosa. During the first study of the Pingliang Formation for radiolarians, Wang (1993) reported the presence of Inanihella penrosei. However, the figures in that paper clearly illustrate specimens of $K$. pingliangensis. Indeed, the wide range of dimensions Wang (1993) measured for elements of the shell, as well as an unmentioned third sphere, which can be clearly seen in Wang (1993, fig. 2.7) suggests assignment to $I$. penrosei was inappropriate.

Since Kalimnasphaera pingliangensis, which occurs in both $N$. gracilis and $C$. bicornis biozones, appears to be facies independent and may prove to be a useful index fossil alongside with Protoceratoikiscum spp., which is regarded as an index fossil for the Sandbian in the radiolarian biozonation of Aitchison et al. (2017b). We note that $K$. pingliangensis occurs mostly in deep marine facies, such as cherts, which may explain its absence in an assemblage from a shallow-water, calcareous section.

Genus Oriundogutta Nazarov and Ormiston in Nazarov, 1988

Type species.-Astroentactinia ramificans Nazarov, 1975 (GIN 4333/6) from Bestamak Formation, SW foothills of Chingiz Range, eastern Kazakhstan, by original designation.

Oriundogutta bella Wang, 1993

Figure 11.2

1991 Oriundogutta bella Wang, p. 249, pl. 1, fig. 14.

1993 Oriundogutta bella Wang, p. 101, pl. 9, figs. 1-13. 1999 ?Oriundogutta bella; Danelian, p. 632, pl. 5, fig. C.
Holotype.-Specimen (NIGPAS-R0116) from Pingliang Formation, Gansu Province, China (Wang, 1993, pl. 9, fig. 11).

Remarks.-The specimen figured as Oriundogutta bella in Wang (1991), which was recovered from the Pingliang Formation, was not accompanied by any species description. Wang (1993) again used the same specimens from his 1991 study, adding some additional specimens, to formally introduce Oriundogutta bella with a proper species description and a designated holotype.

Only seven spines are visible. However, spine orientation suggests one other spine may be accommodated in the vacant surface towards lower-right position of the shell. The dimensions of shell elements correspond well with the holotype. The type material comes from older strata in the same section.

\section{Oriundogutta ?miscella minuta Wang, 1993 Figure 11.3}

1993 Oriundogutta miscella minuta Wang, p. 101, pl. 10, figs. $16,17$.

Holotype.-Specimen (NIGPAS-R0135) from the Pingliang Formation, Gansu Province, China (Wang, 1993, pl. 10, fig. 17).

Remarks.-Poorly preserved single specimen shows slightly larger shell dimensions (shell $\varnothing=104 \mu \mathrm{m}$ and spine length is $\sim 54 \mu \mathrm{m})$ than that of the holotype $(\varnothing=80-100 \mu \mathrm{m}$ and length of primary spines $=30-50 \mu \mathrm{m}$ ). The number of spines is not predictable, but appears to be more than eight. The specimen is thus tentatively assigned to $O$. ?miscella minuta.

\section{Results}

Radiolarians were extracted from samples SEES/140703-49 and SEES/140703-55, with the latter being stratigraphically higher. These samples yielded a diverse, well-preserved assemblage with 19 radiolarian species representing 12 genera. Faunal composition reflecting the taxonomic assignments and relative abundances in yielding samples are presented in Supplemental Data 8. Two new genera, Geminusphaera n. gen. and Protopylentonema n. gen., and six new species (Geminusphaera grandis n. gen. n. sp. Geminusphaera kongtongensis n. gen. n. sp., Haplotaeniatum implexa $\mathrm{n}$. sp., Inanigutta quadrispinosa $\mathrm{n}$. sp., Kalimnasphaera pingliangensis n. sp., and Protopylentonema ordosensis n. gen. n. sp.) are introduced. Although the Guanzhuang section is famous for graptolites, only SEES/140703-49 yielded recognizable taxa. Syndyograptus sinensis Mu, 1963, and Amphigraptus divergens (Hall, 1859), both of which have 


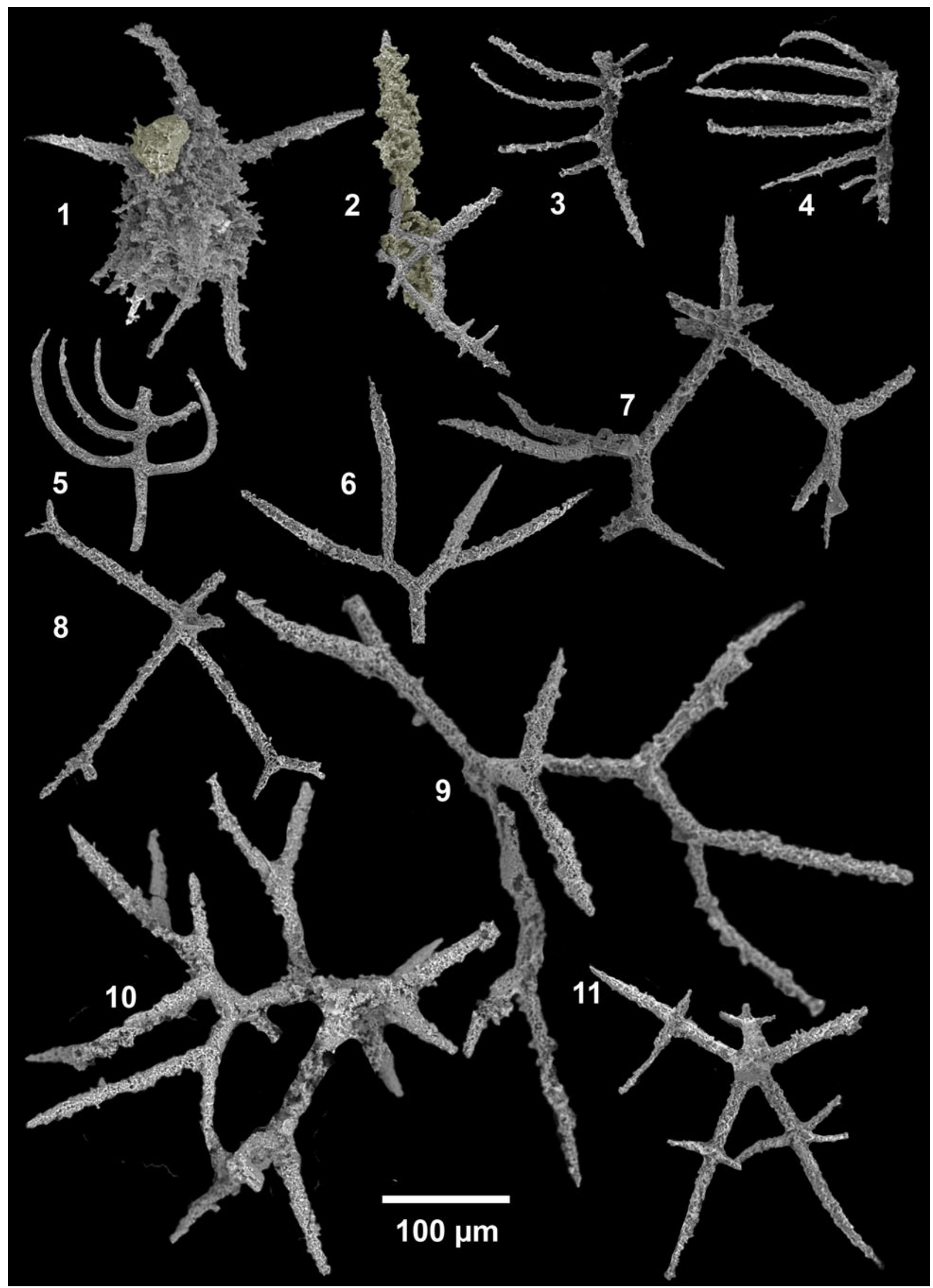


Figure 12. SEM images of radiolarians extracted from bed 5 of the Pingliang Formation in the Guanzhuang section, Gansu, China. (1-5) Gansuceratoikiscum guanzhuangensis SEES/140703-49-GG1-5; (6, 9, 10) Palaeoephippium radices Goodbody, (6) bifurcating fragments, SEES/140703-55-PR1, (9, 10) SEES/ 140703-49-PR1-2; (7, 8) Palaeoephippium spp., SEES/140703-55-PSP1-2; (11) Bissylentactinia bifida Nazarov and Popov, SEES/140703-55-BB1. Scale bar is $100 \mu \mathrm{m}$.

ranges in the $C$. bicornis Biozone (Chen et al., 2017; Fig. 2), constrain the sample to the upper Sandbian. Conodonts also were recovered from the acid residues and include the shortranging Sandbian forms Venoistodus venustus (Stauffer, 1935) and Costiconus ethingtoni (Fåhraeus, 1966) (Wang et al., 2013), constraining the radiolarian assemblage to a narrow window within the Baltoniodus gerdae subzone of the Amorphognathus tvaerensis Biozone. The long-ranging Sandbian taxon Periodon aculeatus was also recovered (see Fig. 2).

\section{Discussion}

Radiolarians are the only siliceous biomineralizing zooplankton known to have participated in the GOBE. The gradual or sudden increment of the taxonomic richness experienced by marine organisms, including radiolarians, during Early to Middle Ordovician is recognizable in many diversity studies conducted regardless of the region (Stigall et al., 2019; Danelian and Monnet, 2021). However, encounters of radiolarians during the GOBE are limited, and might indicate an ecological preference of early Paleozoic radiolarians over preservation biases. Various paleogeographic reconstructions for Late Ordovician time offer various scenarios, each backed by a variety of geophysical and paleontological evidence that show positions of Kazakh terranes, South and North China, and the Australian sector of Gondwana, all near or adjacent to the equator. The relative distribution of positions for the central and eastern Asian blocks continues to be a topic of on-going debate (Cocks and Torsvik, 2020). These adjacent terranes account for a majority of Late Ordovician radiolarian occurrences: Malongulli and Ballast formations, Australia (Webby and Blom, 1986; Goto and Ishiga, 1991; Goto et al., 1992; Iwata et al., 1995; Noble and Webby, 2009); Pingliang and Zhaolaoyu formations, North China (Wang, 1993; Song et al., 2000; Wang et al., 2010); Wufeng Formation, South China (Wang and Zhang, 2011; Zhang et al., 2018); and Ulkuntas Horizon, Kazakhstan (Nazarov and Popov, 1980), reported to date. The rest lie in the Laurentian and Baltic paleo-shelves in the Hanson Creek Formation, Nevada (Dunham and Murphy, 1976; Renz, 1990), and Saunja Formation, Estonia (Nazarov and Nolvak, 1983), respectively. Radiolarian assemblages reported from all these isolated paleogeographical sites show unique faunal compositions, despite sharing some genera and species. The distribution of known Late Ordovician radiolarian occurrences on a paleogeographical map highlights their concentration in areas of low latitude (Fig. 13). Many researchers estimate temperatures were close to modern-day, equatorial sea surface temperatures $\left(25-32^{\circ} \mathrm{C}\right.$ ) around low paleo-latitudes (up to $40^{\circ} \mathrm{N} / \mathrm{S}$ ) during Late Ordovician time (Trotter et al., 2008; Song et al., 2019; Cocks and Torsvik, 2020). The propensity of Late Ordovician radiolarians to flourish in this range of sea surface temperatures is a characteristic trend shared by other marine clades. Kröger (2018) estimated that peak diversities for all marine biota of the Late Ordovician were concentrated around $0-30^{\circ}$ paleolatitudes, whereas Early to Middle Ordovician peaks lay within zones between $15-45^{\circ}$.

Despite sharing similar SSTs, abiotic factors, such as different levels of dissolved oceanic $\mathrm{Si}$ and shelf environment changes, triggered by fluctuating sea levels might have had a cumulative effect at local and global scales, possibly causing the diversity differences among radiolarian assemblages in different micro-continents. While the levels of dissolved silica in oceans control the biomineralization of radiolarian skeletons, speciation within a population is naturally promoted by geographic barriers and entering of members from an adjacent niche, which could occur as results of intermittent sea-level changes (Kidder and Tomescu, 2016; Stigall et al., 2017).

The Katian Hanson Creek Formation in Nevada (Dunham and Murphy, 1976; Renz, 1990) and Malongulli Formation in Australia (Webby and Blom, 1986; Goto et al., 1992; Noble and Webby, 2009) host the most diverse radiolarian assemblages, and genera representing all four orders (Albaillellaria, Archaeospicularia, Entactinaria, and Spumellaria) have been reported to have existed at the time. Those two assemblages share many species, although the Laurentia and Australian sectors of Gondwana were geographically remote from one another during the Katian. In contrast, the Wufeng Formation in the South China block, positioned relatively near the slightly older high-diversity terrane of Australia, contained a less-diverse assemblage dominated by inaniguttids. These upper KatianHirnantian assemblages on the shelves of the South China block might have been influenced by the dominating population of inaniguttids dispersed in the adjacent North China block during the Sandbian. The neighboring shelves of the Kazakh terranes, which were a hotspot of radiolarians during the Middle Ordovician, have only a single report of Late Ordovician radiolarians. Only the Baltic radiolarian assemblage reported to date is coeval with our study, and it is the assemblage located farthest from the paleo-equator. Neither the abundance nor preservation of both Kazakh and Baltic assemblages reported several decades ago is sufficient to remark on their diversity, despite sharing $H$. baltica, a rare species that was also found in the Pingliang Formation. Given the preference of Late Ordovician radiolarians for warm waters, the drop of SSTs that accompanied the Hirnantian glaciation (Trotter et al., 2008; Cocks and Torsvik, 2020) might have negatively affected radiolarian diversity and abundance.

During the last phase of GOBE in the Late Ordovician, most of the marine clades, including radiolarians, started to adapt to the new equilibrium they reached with their ecosystems. The response of radiolarians mainly included structural adaptations, such as development of a pylome that was initiated by Darriwilian time in Triplococcus, Westernbrookia, and Protopylentonema n. gen., and successfully passed on to Late Ordovician Kalimnasphaera, Borisella, and Sandbian members of Protopylentonema n. gen. By Late Ordovician time, bandage- 


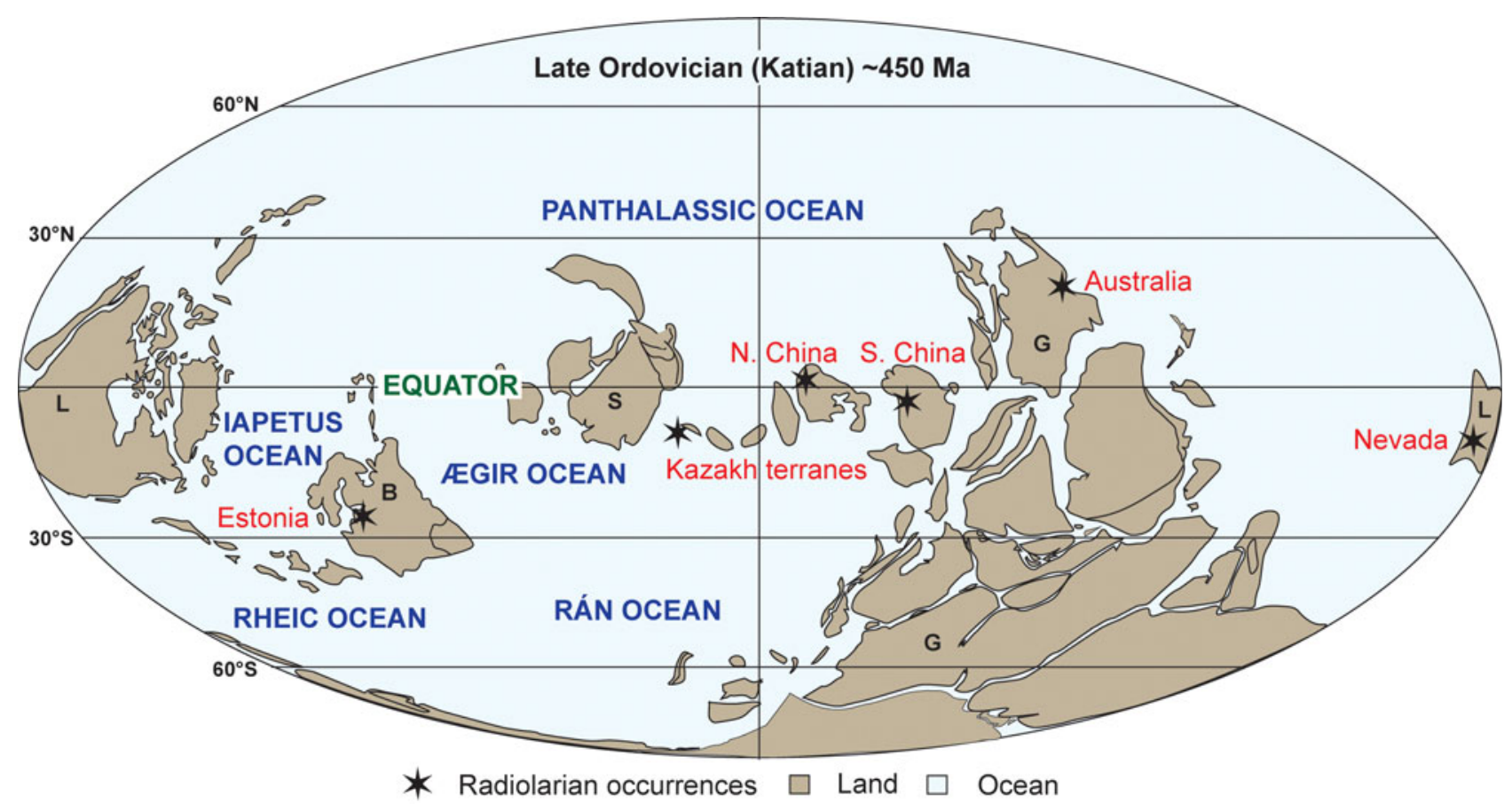

Figure 13. Global distribution of known late Ordovician radiolarian localities displayed on a paleogeographic reconstruction model redrawn from Cocks and Torsvik (2020, fig. 6). B: Baltica, G: Gondwana, L: Laurentia, S: Siberia.

type shell wall-bearing antygoporids and aspiculids of the Middle Ordovician were mostly replaced by solid, thick skeleton-bearing inaniguttids (Kalimnasphaera, Geminusphaera n. gen., Inanibigutta, Inanigutta, and Oriundogutta), increasing the robustness of the skeleton and adapting to both shallow- and deep-water facies. Although radiolarian discoveries are usually subjected to strong preservation and collection biases, which shadows true relative species abundances, many studies conducted for Ordovician radiolarians confirm the dominating occurrence of inaniguttids (Nazarov, 1988; Wang, 1993; Danelian and Clarkson, 1998; Danelian and Floyd, 2001; Maletz and Bruton, 2008; Maletz et al., 2009; Noble and Webby, 2009; Kachovich and Aitchison, 2020; Perera et al., 2020). This indicates that the Inaniguttidae were the most successful family to diversify during the GOBE.

Since the GOBE is recognized as a speciation event, the identification of phylogenetic differences in the fossil skeleton is crucial. The establishment of all six new species and two new genera in this study was supported with use of micro-CT imagery after considering their initial skeleton structure rather than skeletal dimensions. Since the Family Inaniguttidae was established, its definition has undergone multiple revisions and emendations because of the abundance of taxa and high degree of morphological variations seen in their skeletons and/ or dimensions even among coeval encounters. Therefore, a diagnosis that emphasizes the nature of the initial skeleton and accompanying primary-level skeletal features, such as spines originating from the initial skeleton (primary spines) and number of shells directly developing from apophyses of primary spines, is required. If those fundamental elements are preferred over the dimensions used for species diagnosis, it is less likely to be affected by ontogenetic change and adaptation to ecological stress conditions, which may cause major phylogenetic misinterpretations.

\section{Acknowledgments}

The research was financially supported by the Australian Research Council grant no. ARC DP 1501013325 (to JCA). We thank C. Evans at the Julius Kruttschnitt Mineral Research Centre, UQ, for conducting micro-CT measurements of the radiolarian specimens. S. Kachovich (UQ) and Z. Yan (CAGS) collected the samples. We also thank journal Editor B. Hunda, Associate Editor P. Noble, and reviewers L. Hui and T. Danelian for their constructive comments that have helped to improve the manuscript. This paper is a contribution to the International Geoscience Programme (IGCP) Project 653, The Onset of the Great Ordovician Biodiversification Event.

\section{Data availability statement}

Data available from the Dryad Digital Repository: http://doi.org/ 10.5061/dryad.gtht76hn2.

\section{References}

Afanasieva, M.S., 1986, Radiolarians of the family Pylentonemidae: Paleontological Journal, v. 3, p. 22-34.

Aitchison, J.C., 1993, Albaillellaria from the New England orogen, Eastern NSW, Australia: Marine Micropaleontology, v. 21, p. 353-367.

Aitchison, J.C., 1998, A Lower Ordovician (Arenig) radiolarian fauna from the Ballantrae Complex, Scotland: Scottish Journal of Geology, v. 34, p. $73-81$.

Aitchison, J.C., Flood, P.G., and Malpas, J., 1998, Lowermost Ordovician (basal Tremadoc) radiolarians from the Little Port Complex, western Newfoundland (Lower Ordovician radiolarians, Newfoundland): Geological Magazine, v. 135, p. 413-419. 
Aitchison, J.C., Suzuki, N., and O’Dogherty, L., 2017a, Inventory of Paleozoic radiolarian species (1880-2016), in Danelian, T., Caridroit, M., Noble, P. and Aitchison, J.C., eds. Catalogue of Paleozoic Radiolarian Genera: Geodiversitas, v. 39, p. 533-637.

Aitchison, J.C., Suzuki, N., Caridroit, M., Danelian, T., and Noble, P., 2017b, Paleozoic radiolarian biostratigraphy, in Danelian, T., Caridroit, M., Noble, P., and Aitchison, J.C., eds. Catalogue of Paleozoic Radiolarian Genera: Geodiversitas, v. 39, p. 503-531.

Amon, E.O., Braun, A., and Ivanov, K.S., 1995, Upper Silurian radiolarians from the southern Urals: Geologica et Paleontologica, v. 29, p. 1-18.

An, T.Y., Zhang, A.T., and Xu, J.M., 1985, Ordovician conodonts from Yaoxian and Fuping, Shaanxi and their stratigraphic significance: Acta Geologica Sinica, v. 59, p. 97-110. [in Chinese with English abstract]

Cao, W., Feng, Q., Feng, F., and Ling, W., 2014, Radiolarian Kalimnasphaera from the Cambrian Shuijingtuo Formation in South China: Marine Micropaleontology, v. 110, p. 3-7.

Caridroit, M., Danelian, T., O'Dogherty, L., Cuvelier, J., Aitchison, J.C., Pouille, L., Noble P., Dumitrica, P., Suzuki, N., Kuwahara, K., Maletz, J., and Feng, Q., 2017, An illustrated catalogue and revised classification of Paleozoic radiolarian genera, in Danelian, T., Caridroit, M., Noble, P., and Aitchison, J.C., eds. Catalogue of Paleozoic Radiolarian Genera: Geodiversitas, v. 39, p. 363-417

Cavalier-Smith, T., 1987, The origin of eukaryotic and archaebacterial cells: Annals of the New York Academy of Sciences, v. 503, p. 17-54.

Chen, J.Y., Zhou, Z.Y., Li, Y.K., Zou, X.P., Wang, Z.H., Luo, K.Q., Yao, B.Q., and She, H., 1984, Ordovician biostratigraphy of western Ordos: Memoirs of the Nanjing Institute of Geology and Palaeontology, Academia Sinica, v. 20, p. 1-31 [in Chinese].

Chen, X., Zhang, Y., Wang, Z., Goldman, D., Bergström, S.M., Fan, J., Finney, S.C., and Chen, Q., 2017, Chapter 2-Biostratigraphy, in Chen, X., Bergström, S.M., Finney, S.C., Zhang, Y., Fan, J., Chen, Q., Goldman, D., Wang, Z., and Ma, X., eds., Darriwilian to Katian (Ordovician) Graptolites from Northwest China: Amsterdam, Elsevier, p. 7-38.

Cheng, Y.N., 1986, Taxonomic studies on upper Paleozoic Radiolaria: National Museum of Natural Science, Taiwan, Special Publication No. 1, 310 p.

Cocks, L.R.M., and Torsvik, T.H., 2020, Ordovician palaeogeography and climate change: Gondwana Research. https://doi.org/10.1016/j.gr.2020.09. 008.

Dai, S., Qiang, L., Tian, C., Xi, H., Luo, J., Li, R., Liang, J., Wang, W., and Li, G., 2019, The multiple stratigraphy study for Ordovician in SW Ordos, China: Acta Geologica Sinica (English Edition), v. 93, p. 98-101.

Danelian, T., 1999, Taxonomic study of Ordovician (Llanvirn-Caradoc) Radiolaria from the Southern Uplands (Scotland, UK): Geodiversitas, v. 21, p. $625-635$

Danelian, T., and Clarkson, E.N.K., 1998, Middle Ordovician Radiolaria from bedded cherts of the Southern Uplands: Scottish Journal of Geology, v. 34, p. 133-137

Danelian, T., and Floyd, J., 2001, Progress in describing Ordovician siliceous biodiversity from the Southern Uplands (Scotland, UK): Transactions of the Royal Society of Edinburgh, Earth Sciences, v. 91, p. 489-498.

Danelian, T., and Monnet, C., 2021, Early Paleozoic radiolarian plankton diversity and the Great Ordovician Biodiversification event: Earth Science Reviews, v. 218, 103672. https://doi.org/10.1016/j.earscirev.2021.103672.

Danelian, T., and Popov, L., 2003, Ordovician radiolarian biodiversity: insights based on new and revised data from Kazakhstan: Bulletin de la Société Géologique de France, v. 174, p. 325-335.

Deflandre, G., 1953, Radiolaires fossils, in Grassé, P.P., ed., Traité de Zoologie: Paris, Masson, p. 389-436.

Deflandre, G., 1963, Pylentonema, nouveau genre de Radiolaire du Viséen: Sphaerellaire ou Nassellaire?: Comptes Rendus Hebdomadaires des Séances de l'Académie des Sciences (Paris), Série D, Sciences Naturelles, v. 257, p. 3981-3984.

De Wever, Dumitrica P., Caulet, J.P., Nigrini, C., and Caridroit, M., 2001, Radiolarians in the Sedimentary Record: Amsterdam, Gordon and Breach Science Publishers, $533 \mathrm{p}$.

Dunham, J.B., and Murphy, M.A., 1976, An occurrence of well-preserved radiolarian from the Upper Ordovician (Caradocian), Eureka County, Nevada: Journal of Paleontology, v. 50, p. 882-887.

Ehrenberg, C.G., 1838, Über die bildung der kreidefelsen und des kreidemergels durch unsichtbare organismen: Abhandlungen der Königlichen Preussichen Akademie der Wissenschaften zu Berlin, v. 1838, p. 59-147.

Ehrenberg. C.G., 1876, Fortsetzung der mikrogeologischen Studienals Gesammt-Uebersicht der mikroskopischen Paläontologie gleichartig analysirter Gebirgsarten der Erde, mit specieller Rücksicht auf den PolycystinenMergel von Barbados: Abhandlungen der Königlichen Preussichen Akademie der Wissenschaften zu Berlin, v. 1876, p. 1-226.

Fåhraeus, L.E., 1966, Lower Viruan (Middle Ordovician) conodonts from the Gullhögen Quarry, southern central Sweden: Sveriges Geologiska Undersökning C, v. 610 , p. $1-40$.
Finney, S.C., Bergström, S.M., Chen, X., and Wang, Z.H., 1999, The Pingliang section, Gansu Province, China: potential as stratotype for the base of the Nemagraptus gracilis Biozone and the base of the global Upper Ordovician: Acta Universitatis Carolinae-Geologica, v. 43, p. 73-75.

Foreman, H.P., 1963, Upper Devonian Radiolaria from the Huron Member of the Ohio Shale: Micropaleontology, v. 9, p. 267-304

Goodbody, Q.H, 1986, Wenlock Palaeoscenidiidae and Entactiniidae (Radiolaria) from the Cape Phillips Formation of the Canadian Arctic Archipelago: Micropaleontology, v. 32, p. 129-157.

Goto, H., and Ishiga, H., 1991, Study of Late Ordovician radiolarians from the Lachlan Fold Belt, Southeastern Australia: Geology Research Report, Shimane University, v. 10, p. 57-62. [in Japanese]

Goto, H., Umeda, M., and Ishiga, H., 1992, Late Ordovician radiolarians from the Lachlan Fold Belt, Southeastern Australia: Memoirs of the Faculty of Science, Shimane University, v. 26, p. 145-170.

Hadding, A.R., 1913, Undre Dicellograptusskiffern i Skåne jämte några därmed ekvivalenta bildningar: Lunds Univesitets Årsskrift, Ny Följd, Afdelning 2, v. 9 , p. $1-90$.

Hall, J., 1859, Notes upon the genus Graptolithus: Palaeontology of New York, Geological Survey of New York, Supplement to v.1, p. 495-522.

Holdsworth, B.K., 1969a, The relationship between the genus Albaillella Deflandre and the ceratoikiscid Radiolaria: Micropaleontology, v. 15, p. 230-236.

Holdsworth, B.K., 1969b, Namurian Radiolaria of the genus Ceratoikiscum from Staffordshire and Derbyshire, England: Micropaleontology, v. 15, p. 221-229.

Holdsworth, B.K., 1971, The ceratoikiscid nature of the radiolarian Lapidopiscum piveteaui Deflandre: Micropaleontology, v. 17, p. 244-248.

Holdsworth, B.K., 1977, Paleozoic Radiolaria: stratigraphic distribution in Atlantic borderlands, in Swain, F.M., ed., Stratigraphic Micropaleontology of Atlantic Basin and Borderlands: Amsterdam, Elsevier, p. 167-184.

Iwata, K., Schmidt, B.L., Leitch, E.C., Allan, A.D., and Watanabe, T., 1995, Ordovician microfossils from the Ballast Formation (Girilambone Group) of New South Wales: Australian Journal of Earth Sciences, v. 42, p. 371-376.

Kachovich, S., and Aitchison, J.C., 2020, Micro-CT study of Middle Ordovician Spumellaria (radiolarians) from western Newfoundland, Canada: Journal of Paleontology, v. 94, p. 417-435.

Kachovich, S., and Aitchison, J.C., 2021, Middle Ordovician (middle Darriwilian) Archaeospicularia and Entactinaria (radiolarians) from the Table Cove Formation, Piccadilly Quarry, Newfoundland, Canada: Journal of Paleontology, v. 95, p. 913-943. https://doi.org/10.1017/jpa.2021.18.

Kachovich, S., Sheng, J., and Aitchison, J.C., 2019, Adding a new dimension to investigations of early radiolarian evolution: Scientific Reports, v. 9, no 6450. https://doi.org/10.1038/s41598-019-42771-0.

Kidder, D.L., and Tomescu, I., 2016, Biogenic chert and the Ordovician silica cycle: Palaeogeography, Palaeoclimatology, Palaeoecology, v. 458, p. 29-38

Kozur, H.W., and Mostler, H., 1982, Entactinaria subordo nov., a new radiolarian suborder: Geologisch Paläontologische Mitteilungen Innsbruck, v. 11, p. $399-414$.

Kröger, B., 2018, Changes in the latitudinal diversity gradient during the Great Ordovician Biodiversification Event: Geology, v. 46, p. 127-130.

Li, H.S., 1994, Middle Silurian radiolarians from Keerhada, Xinjiang: Acta Micropalaeontologica Sinica, v. 11, p. 259-272.

Li, H.S., 1995, New genera and species of middle Ordovician Nassellaria and Albaillellaria from Baijingsi, Quilian Mountains, China: Scientia Geologica Sinica, v. 4, p. 331-346.

MacDonald, E.W., 2004, Palaeoscenidiidae (Radiolaria) from the lower Silurian of the Cape Phillips Formation, Cornwallis Island, Nunavut, Canada: Journal of Paleontology, v. 78, p. 257-274.

Maletz, J., 2007, The Early Ordovician Beothuka terranova (Radiolaria) faunal assemblage in western Newfoundland: Palaeontologische Zeitschrift, v. 81, p. $71-82$.

Maletz, J., 2011, Radiolarian skeletal structures and biostratigraphy in the early Palaeozoic (Cambrian-Ordovician): Palaeoworld, v. 20, p. 116-33.

Maletz, J., and Bruton, D.L., 2008, The Middle Ordovician Proventocitum procerulum radiolarian assemblage of Spitsbergen and its biostratigraphic correlation: Palaeontology, v. 51, p. 1181-1200.

Maletz, J., Albanesi, G.L., and Voldman, G.G., 2009, Lower Darriwilian radiolarians from the Argentine Precordillera: Geobios, v. 42, p. 53-61.

Mu, E.Z., 1963, On the complication of graptolite rhabdosome: Acta Palaeontologica Sinica, v. 11, p. 346-377.

Nazarov, B.B., 1975, Lower and middle Paleozoic Radiolaria of Kazakhstan (methods of investigation, systematics and stratigraphy): Akademiya Nauk SSSR, Trudy Geologicheskogo Instituta, Akademiya Nauk SSSR, v. 275, p. 1-202. [in Russian]

Nazarov, B.B., 1988, Practical manual of microfauna of the USSR. Paleozoic Radiolaria: Leningrad, Nedra, v. 2, 232 p. [in Russian]

Nazarov, B.B., and Nolvak, J., 1983, Radiolarians from Upper Ordovician of Estonia: Izvestiya Akademii Nauk Estonskoy SSR, Geologiya, v. 32, p. 1-8. [in Russian with English summary] 
Nazarov, B.B., and Ormiston, A., 1984, Tentative system of Paleozoic Radiolaria, in Petrushevskaya, M.G., and Stepanjants, S.D., eds., Morphology, Ecology and Evolution of Radiolarians: Material from the IV Symposium of European Radiolarists EURORAD IV, Academiya Nauk SSSR, Zoological Institute, Leningrad, USSR, p. 64-87.

Nazarov, B.B., and Ormiston, A.R., 1993, New biostratigraphically important Paleozoic Radiolaria of Eurasia and North America, in Blueford, J.R., and Murchey, B.L., eds., Radiolaria of Giant and Subgiant Fields in Asia: Nazarov Memorial Volume, Micropaleontology, Special Publication, v. 6. p. $22-60$.

Nazarov, B.B. and Popov, L.Y., 1976, Radiolarians, ecardine brachiopods and organisms of uncertain systematic position from the Middle Ordovician of eastern Kazakhstan: Paleontological Journal, v. 4, p. 407-416.

Nazarov, B.B., and Popov, L.Y., 1980, Stratigraphy and fauna of the siliceous carbonate sequence of the Ordovician of Kazakhstan (Radiolaria and inarticulate brachiopods): Transactions of the Geological Institute of the Soviet Akademy of Sciences, v. 331, p. 1-192. [in Russian]

Nazarov, B.B., Popov, L.Y., and Apollonov, M., 1975, Lower Paleozoic Radiolaria in Kazakhstan: Izvestiya Akademii Nauk SSSR, Serija Geologičeskaja, v. 10, p. 96-105 [in Russian].

Noble, P.J., 1994, Silurian radiolarian zonation for the Caballos Novaculite, Marathon Uplift, West Texas: Bulletins of American Paleontology, v. 106, p. $1-55$.

Noble, P.J., and Aitchison, J.C., 1995, Status of Ordovician and Silurian Paleozoic radiolarian studies in North America, in Blome, C.D., Whalen, P.M. and Reed, K.M., eds., Siliceous Microfossils, Short Courses in Paleontology, University of Tennessee, Knoxville: Paleontological Society Publication No. 8, p. 19-30.

Noble, P.J., and Lenz, A.C., 2007, Upper Wenlock Ceratoikiscidae (Radiolaria) from the Cape Phillips Formation, Arctic Canada: Journal of Paleontology, v. 81 , p. 1044-1052.

Noble, P.J., and Webby, B.D., 2009, Katian (Ordovician) radiolarians from the Malongulli Formation, New South Wales, Australia, a re-examination: Journal of Paleontology, v. 83, p. 548-561.

Noble, P., Aitchison, J.C., Danelian, T., Dumitrica, P., Maletz, J., Suzuki, N., Cuvelier, J., Caridroit, M., and O'Dogherty, L., 2017, Taxonomy of Paleozoic radiolarian genera, in Danelian, T., Caridroit, M., Noble, P., and Aitchison, J.C., eds., Catalogue of Paleozoic Radiolarian Genera: Geodiversitas, v. 39. p. 419-502.

Perera, S., Aitchison, J.C., and Nothdurft, L., 2020, Middle Ordovician (Darriwilian) radiolarians from the Crawford Group, Scotland: Geological Magazine, v. 157, p. 2033-2043.

Pouille, L, Danelian, T, Ghobadi, P.M., and Popov, L.E., 2013, New and revised inaniguttid Radiolaria and associated trilobites from the upper Darriwilian (Ordovician) Shundy Formation of Kazakhstan: Journal of Paleontology, v. 87, p 1143-1159.

Pouille, L, Danelian, T, and Maletz, J., 2014, Radiolarian diversity changes during the late Cambrian-Early Ordovician transition as recorded in the Cow Head Group of Newfoundland (Canada): Marine Micropaleontology, v. 110, p. $25-41$.

Renz, G.W., 1988, Silurian radiolarians of the genus Ceratoikiscum from the Canadian Arctic: Micropaleontology, v. 34, p. 260-267.

Renz, G.W., 1990, Late Ordovician (Caradocian) radiolarians from Nevada: Micropaleontology, v. 36, p. 367-377.

Riedel, W.R., 1967, Some new families of Radiolaria: Proceedings of the Geological Society of London, v. 1640, p. 148-149.

Ruedemann, R., and Wilson, T.Y., 1936, Eastern New York Ordovician cherts: Bulletin of the Geological Society of America, v. 74, p. 1535-1586.

Siveter, D.J., Aitchison, J.C., Siveter, D.J., and Sutton, M.D., 2007, The Radiolaria of the Herefordshire Konservat-Lagerstätte (Silurian), England: Journal of Micropalaeontology, v. 26, p. 87-95.

Song, H., Wignall, P.B., Song, H., Dai, X., and Chu, D., 2019, Seawater temperature and dissolved oxygen over the past 500 million years: Journal of Earth Science, v. 30, p. 236-243.

Song, Q.Y., Cui, Z.L., Hua, H., and Wang, X.R., 2000, The Late Ordovician Radiolaria from Fuping of Shaanxi Province, China: Journal of Northwest University (Natural Science Edition), v. 30, p. 65-68.

Stauffer, W.C., 1935, Conodonts of the Glenwood Beds: Bulletin of the Geological Society of America, v. 46, p. 125-168.

Stigall, A.L., Bauer, J.E, Lam, A.R., and Wright, D.F., 2017, Biotic immigration events, speciation, and the accumulation of biodiversity in the fossil record: Global and Planetary Change, v. 148, p. 242-257.

Stigall, A.L., Edwards, C.T., Freeman, R.L., and Rasmussen, C.M.Ø., 2019, Coordinated biotic and abiotic change during the Great Ordovician Biodiversification Event: Darriwilian assembly of early Paleozoic building blocks: Palaeogeography, Palaeoclimatology, Palaeoecology, v. 530, p. 249-270.

Sun, J., Yang, L., Dong, Y., Yang, X., Peng, Y., and Zhao, J., 2020, Permian tectonic evolution of the southwestern Ordos Basin, North China:
Integrating constraints from sandstone petrology and detrital zircon geochronology: Geological Journal, v. 55, p. 8068-8091. https://doi.org/10. 1002/gj.3916.

Sun, Y.C., 1933, Ordovician and Silurian graptolites from China: The Geological Survey of China, Palaeontologia Sinica, ser. B, v. 14, p. 1-52.

Suzuki, N., 2006, Ontogenetic growth and variation in the skeletal structure of two late Neogene Sphaeropyle species (Polycystina radiolarians): Journal of Paleontology, v. 80, p. 849-66.

Trotter, J.A., Williams, I.S., Barnes, C.R., Lécuyer, C., and Nicoll, R.S., 2008, Did cooling oceans trigger Ordovician biodiversification? evidence from conodont thermometry: Science, v. 321, p. 550-554.

Trubovitz, S., and Stigall, A.L., 2018, Ecological revolution of Oklahoma's rhynchonelliform brachiopod fauna during the Great Ordovician Biodiversification Event: Lethaia, v. 51, p. 277-286.

Umeda, M., Goto, H., and Ishiga, H., 1992, Middle Ordovician radiolarians from the Lachlan Fold Belt, Southeastern Australia: Memoirs of Faculty of Science, Shimane University, v. 26, p. 131-140.

Wakamatsu, H., Sugiyama, K., and Furutani, H., 1990. Silurian and Devonian radiolarians from the Kurosegawa Tectonic Zone, southwest Japan: Journal of Earth Sciences, Nagoya University, v. 37, p. 157-192.

Wang, Y., 1991, On progress in the study of Paleozoic radiolarians in China: Acta Micropalaeontologica Sinica, v. 8, p. 237-251

Wang, Y., 1993, Middle Ordovician radiolarians from the Pingliang Formation of Gansu Province, China, in Blueford, J.R., and Murchey, B.L., eds., Radiolaria of Giant and Subgiant Fields in Asia: Nazarov Memorial Volume, Micropaleontology Special Publication No. 6. p. 98-114.

Wang, Y., and Zhang, Y.D., 2011, Radiolarian fauna of the Wufeng Formation (Upper Ordovician) in Lunshan Area, Jiangsu and its geological significance: Acta Micropalaeontologica Sinica, v. 28, p. 251-260.

Wang, Y.J., Cheng, J.F., and Zhang, Y.D., 2010, Fossil preservation modes and functional discussion of the basic structures of a new radiolarian genus Gansuceratoikiscum Wang gen. nov.: Acta Palaeontologica Sinica, v. 49, p. $472-476$.

Wang, Z.H., Bergström, S.M., Zhen, Y.Y., Chen, X., and Zhang, Y.D., 2013, On the integration of Ordovician conodont and graptolite biostratigraphy: new examples from Gansu and Inner Mongolia in China: Alcheringa, v. 37 , p. $510-528$.

Wang, Z.T., Zhou, H.R., Wang, X.L., Zhang, Y.S., Jing, X.C., and Xing, E.Y., 2015a, Ordovician geological events group in the West and South Ordos Basin: Acta Geologica Sinica, v. 89, p. 990-2004. [in Chinese with English abstract]

Wang, Z.T., Zhou, H.R., Wang, X.L., Jing, X.C., and Zhang, Y.S., 2015b, Volcanic event records at the southwestern Ordos Basin: the message from geochemical and zircon U-Pb geochronology of K-bentonites from Pingliang Formation, Shaanxi and Gansu region: Acta Petrologica Sinica, v. 31, p. 2633-2654. [in Chinese with English abstract]

Webby, B.D., and Blom, W., 1986, The first well-preserved radiolarians from the Ordovician of Australia: Journal of Paleontology, v. 60, p. 145-157.

Won, M.Z., 1983, Radiolarien aus dem Unterkarbon des Rheinischen Schiefergebirges (Deutschland): Palaeontographica, Abteilung A, PalaozoologieStratigraphie, v. 182, p. 116-175.

Won, M.Z., and Below, R., 1999, Cambrian Radiolaria from the Georgina Basin, Queensland, Australia: Micropaleontology, v. 45, p. 325-363.

Won, M.Z., and Iams, W.J., 2002, Late Cambrian radiolarian faunas and biostratigraphy of the Cow Head Group, western Newfoundland: Journal of Paleontology, v. 76, p. 1-33

Won, M.Z., and Iams, W.J., 2011, Earliest Arenig radiolarians from the Cow Head Group, Western Newfoundland: Journal of Paleontology, v. 85, p. 156-77.

Won, M.Z., and Iams, W.J., 2013, Early Ordovician (early Arenig) radiolarians from the Cow Head Group of the Little Port Complex fauna, Western Newfoundland: Palaeoworld, v. 22, p. 10-31.

Won, M.Z., and Iams, W.J., 2015a, Early/Middle Arenig (late Floian) radiolarian faunal assemblages from Cow Head Group, Western Newfoundland: Palaeontographica Abteilung A, v. 304, p. 1-63.

Won, M.Z., and Iams, W.J., 2015b, Review of the Beothuka terranova assemblage and characteristics of the middle Arenig (Ordovician, latest Floian) radiolarian assemblage from the Cow Head Group, Newfoundland: Neues Jahrbuch für Geologie und Paläontologie-Abhandlungen, v. 278, p. 1-21.

Won, M.Z., Blodgett, R.B., and Nestor, V., 2002, Llandoverian (early Silurian) radiolarians from the Road River Formation of east-central Alaska and the new family Haplotaeniatumidae: Journal of Paleontology, v. 76, p. 941-964.

Won, M.Z., Iams, W.J., and Reed, K., 2005, Earliest Ordovician (early to middle Tremadocian) radiolarian faunas of the Cow Head Group, Western Newfoundland: Journal of Paleontology, v. 79, p. 433-459.

Won, M.Z., Iams, W.J., and Reed, K., 2007, Late Tremadocian radiolarian faunas and biostratigraphy of the Cow Head Group, Western Newfoundland, Canada: Journal of the Korean Earth Science Society, v. 28, p. 497-540. 
Wu, S.J., Li, Z.H., Hu, J.M., and Gong, W.B., 2014, Confirmation of Ordovician sediments in south margin of Ordos Basin by SHRIMP U-Pb zircon dating of volcanic tuff interlayers and its significance: Geological Review, v. 60, p. 903-912. [in Chinese with English abstract]

Yang, A.J.R., Loon, T.V., Jin, X., Jin, Z., Han, Z., Fan, A., and Liu, Q., 2019, From divergent to convergent plates: resulting facies shifts along the southern and western margins of the Sino-Korean Plate during the Ordovician: Journal of Geodynamics, v. 129, p. 149-161.

Yang, F., Chen, G., Chen, Q., Ding, C., Gao, M., Lei, P.P., Zhang, W.L., Shi, X.L., and Tong, M.J., 2015, U-Pb dating of detrital zircon from Upper Ordovician Pingliang Formation in southwest margin of the Ordos Basin and provenance analysis: Geological Review, v. 61, p. 172-182. [in Chinese with English abstract]

Yang, F., Chen, G., Kang, Y., Ma, D., Chen, Q., Tao, T., and Deliang, F., 2020, Late Ordovician provenance and depositional setting in the southwestern Ordos Block, China: constraints from zircon U-Pb geochronology: Geoscience Journal, v. 24, p. 121-139.
Yi, Y., Yuan, A., Aitchison, J.C., and Feng, Q., 2018, Upper Darriwilian (Middle Ordovician) radiolarians and ostracods from the Hulo Formation, Zhejiang Province, South China: Journal of Earth Science, v. 29, p. 886899.

Zhang, B.H., Zhang, J., Zhao, H., Nie, F.J., Wang, Y.N., and Zhang, Y.P., 2019, Tectonic evolution of the western Ordos Basin during the Palaeozoic-Mesozoic time as constrained by detrital zircon ages: International Geology Review, v. 61, p. 461-480.

Zhang, Z., Luo, H., and Zhang, Y.D., 2018, Radiolaria faunas of the Wufeng Formation (Upper Ordovician) at Lunshan, Jiangsu Province and Yihuang-1 Well, Yichang, Hubei Province, China: Acta Micropalaeontologica Sinica, v. 35, p. 170-180. [in Chinese with English abstract]

Zhylkaidarov, A., 1999, Conodonts from Ordovician ophiolites of central Kazakhstan: Acta Palaeontologica Polonica, v. 43, p. 53-68.

Accepted: 5 August 2021 